\title{
Possible Roles of Rhizospheric and Endophytic Microbes to Provide a Safe and Affordable Means of Crop Biofortification
}

\author{
Yee-Shan $\mathrm{Ku}^{\dagger}{ }^{\dagger}$, Hafiz Mamoon Rehman ${ }^{\dagger}$ and Hon-Ming Lam * ${ }^{\mathbb{C}}$ \\ Centre for Soybean Research of the State Key Laboratory of Agrobiotechnology and School of Life Sciences, \\ The Chinese University of Hong Kong, Shatin, Hong Kong, China; ysku@ymail.com (Y.-S.K.); \\ hafizmamoonrehman@cuhk.edu.hk (H.M.R.) \\ * Correspondence: honming@cuhk.edu.hk; Tel.: +852-3943-6336 \\ + The authors contributed equally to this article.
}

Received: 29 September 2019; Accepted: 14 November 2019; Published: 16 November 2019

\begin{abstract}
Biofortification has been used to improve micronutrient contents in crops for human consumption. In under-developed regions, it is important to fortify crops so that people can obtain essential micronutrients despite the limited variety in their diets. In wealthy societies, fortified crops are regarded as a "greener" choice for health supplements. Biofortification is also used in crops to boost the contents of other non-essential secondary metabolites which are considered beneficial to human health. Breeding of elite germplasms and metabolic engineering are common approaches to fortifying crops. However, the time required for breeding and the acceptance of genetically modified crops by the public have presented significant hurdles. As an alternative approach, microbe-mediated biofortification has not received the attention it deserves, despite having great potential. It has been reported that the inoculation of soil or crops with rhizospheric or endophytic microbes, respectively, can enhance the micronutrient contents in various plant tissues including roots, leaves and fruits. In this review, we highlight the applications of microbes as a sustainable and cost-effective alternative for biofortification by improving the mineral, vitamin, and beneficial secondary metabolite contents in crops through naturally occurring processes. In addition, the complex plant-microbe interactions involved in biofortification are also addressed.
\end{abstract}

Keywords: biofortification; plant growth-promoting bacteria; endophytes; arbuscular mycorrhizal fungi; sustainable agriculture; plant-microbe interaction

\section{Introduction}

It is critical for modern agriculture to continue feeding the expanding world population. To support the ever-growing populations, strategies have been employed to maximize the biomass production. One of the famous examples is the "green revolution" which has significantly boosted crop yields to combat hunger. Besides the yield in biomass, the nutritional values of crops are another important consideration for providing proper nutrition. Apart from caloric intake and macronutrients such as nitrogen $(\mathrm{N})$, phosphate $(\mathrm{P})$, and potassium $(\mathrm{K})$, humans also depend on food crops for obtaining certain micronutrients. The malnutrition due to insufficient dietary intake of micronutrients such as minerals and vitamins is regarded as the "hidden hunger". It is predicted that the problem of hidden hunger will be intensified by climate change [1]. For example, it is predicted that the increasing anthropogenic carbon dioxide emission could intensify iron $(\mathrm{Fe})$ deficiency because several crops were found to have lower Fe levels when grown under increased atmospheric $\mathrm{CO}_{2}$ concentrations [2]. Fe deficiency is one of the most common forms of micronutrient deficiency worldwide [3]. FAO data 
reveal that both hunger and "hidden hunger" in sub-Saharan Africa are of concern [4]. In other areas of the world, although the dietary energy intake is satisfactory, "hidden hunger" is still an issue to be addressed [4].

The enrichment of micronutrients in crops is known as biofortification, which has been a common practice for combatting "hidden hunger" [5-7]. Current strategies of biofortification include the application of organic and chemical fertilizers, breeding of elite germplasms, and metabolic engineering [8-11]. The advantages and the drawbacks of these strategies have been extensively summarized in previous reviews [8-11]. For example, breeding and CRISPR/Cas9 technologies can be used to enhance the nutritional values of crops but they are time-consuming, expensive, and are faced with numerous regulatory issues regarding genetically modified organisms (GMOs). Using soil microbes to increase the bioavailability of micro- and macronutrients in the soil is the cheapest, quickest, and most sustainable way to increase the concentrations of micronutrients in our diets while restoring soil health at the same time. In view of the environmental threats from the excessive use of organic and chemical fertilizers, the complexity of selecting suitable germplasms for breeding, and the hurdles to launching transgenic crops due to safety concerns and public acceptance [8-12], the use of microbes for biofortification has been suggested as a "greener" alternative for sustainable agriculture in recent years because it makes use of naturally occurring biological processes. Besides being "greener", the use of microbes for biofortification provides unique benefits in some cases, such as the enrichment of vitamin $\mathrm{B}_{12}$, which is only synthesized by bacteria and archaea but not plants. In this review, we will discuss several examples of microbe-mediated crop fortification to highlight the feasibility and benefits of this alternative approach to biofortification. Satisfying the dietary requirements of minerals and vitamins by human have been a concern. In a joint expert consultation between $\mathrm{FAO}$ and WHO, food-based approaches to meeting the requirements of $\mathrm{Fe}, \mathrm{Zn}$, vitamin $\mathrm{A}$, folate, and vitamin $\mathrm{C}$ were discussed [13]. In this review, microbe-mediated biofortification of these micronutrients and other health-beneficial nutrients, including flavonoids and saponins, will be discussed. The use of both rhizospheric and endophytic microbes will be featured in examples of microbe-mediated biofortification in food crops. Examples of currently biofortified crops are summarized in Table 1, followed by the type of microbes used for the biofortification and their impacts on the crop plants. Figure 1 illustrates the complex processes of microbe-mediated biofortification. In addition, the suppression of pathogens by beneficial soil microbes and the influence on soil microbe communities by plants will also be discussed. 
Table 1. Current examples of microbe-mediated biofortified crops.

\begin{tabular}{|c|c|c|c|c|c|}
\hline Crop & Microbe & Type of microbe & Tissue & Impact & Reference \\
\hline Blackberry & Pseudomonas fluorescens N21.4 & Rhizospheric bacterium & Fruit & Improved flavonoid level & {$[14,15]$} \\
\hline Brassica juncea & $\begin{array}{c}\text { Bacillus toyonensis } \\
\text { (MG430287), } \\
\text { Rhodococcus hoagii } \\
\text { (MG432495), } \\
\text { Lysinibacillus mangiferihumi } \\
\text { (MG432492), and Lysinibacillus fusiformis } \\
\text { (MG430290) }\end{array}$ & Rhizospheric bacteria & $\begin{array}{l}\text { Root, stem, } \\
\text { and leaf }\end{array}$ & Increased Fe contents & [16] \\
\hline $\begin{array}{l}\text { Chickpea and } \\
\text { pigeonpea }\end{array}$ & $\begin{array}{c}\text { Pseudomonas plecoglossicida } \\
\text { SRI-156, } \\
\text { Brevibacterium antiquum SRI-158, } \\
\text { Bacillus altitudinis } \\
\text { SRI-178, Enterobacter ludwigii SRI-211, E. ludwigii } \\
\text { SRI-229, } \\
\text { Acinetobacter tandoii SRI-305, and Pseudomonas monteilii } \\
\text { SRI-360 }\end{array}$ & Rhizospheric bacteria & Grain & $\begin{array}{l}\text { Improved contents of Fe (up to } 18 \% \text { and } \\
12 \% \text { ), } \mathrm{Zn} \text { (up to } 23 \% \text { and } 5 \% \text { ), Cu (up to } \\
19 \% \text { and } 8 \% \text { ), Mn (up to } 2 \% \text { and } 39 \% \text { ) and } \\
\text { Ca (up to } 22 \% \text { and } 11 \% \text { ) }\end{array}$ & [17] \\
\hline \multirow{2}{*}{ Chickpea } & Funneliformis mosseae, Rhizophagus irregularis & Arbuscular mycorrhizal fungi & Grain & Increased protein, $\mathrm{Fe}$, and $\mathrm{Zn}$ contents & [18] \\
\hline & Isolates of actinobacteria & Rhizospheric bacteria & Seeds & $\begin{array}{l}\text { Increased Fe }(10 \%-38 \%), \mathrm{Zn}(13 \%-30 \%), \\
\mathrm{Ca}(14 \%-26 \%), \mathrm{Cu}(11 \%-54 \%) \text { and } \mathrm{Mn} \\
\quad(18 \%-35 \%) \text { and } \mathrm{Mg}(14 \%-21 \%)\end{array}$ & [19] \\
\hline \multirow{2}{*}{ Lettuce } & Glomus fasciculatum & Arbuscular mycorrhizal fungus & Leaf & Improved ascorbate level and fresh weight & [20] \\
\hline & $\begin{array}{c}\text { Glomus intraradices (Schenck and Smith) and Glomus } \\
\text { mosseae [(Nicol. and Gerd.) Gerd. and Trappe] }\end{array}$ & Arbuscular mycorrhizal fungi & Leaf & Improved ascorbate level and fresh weight & [20] \\
\hline Oil palm & Hendersonia toruloidea & Endophytic fungus & Leaf & Improvement of thiamine biosynthesis & {$[21,22]$} \\
\hline Okra & Azotobacter sp. and cyanobacterium (e.g., Calothrix sp.) & Rhizospheric bacteria & Fruit & Increased concentration of $\mathrm{Zn} 60 \%-70 \%$ & [23] \\
\hline Onion & Rhizophagus irregularis & Arbuscular mycorrhizal fungus & Bulb & $\begin{array}{l}\text { Improved biomass production, the } \\
\text { abundance of vitamin B1 and its analogues, } \\
\text { and organic acids concentration }\end{array}$ & [24] \\
\hline Pak choi & $\begin{array}{c}\text { Funneliformis mosseae, Glomus versiforme, and } \\
\text { Rhizophagus intraradices }\end{array}$ & Arbuscular mycorrhizal fungi & Shoot & $\begin{array}{l}\text { Reduced concentrations of } \mathrm{Pb}(\text { by } \\
20.6 \%-67.5 \% \text { ) and } \mathrm{Cd}(\text { by } 14.3 \%-54.1 \%) \text { in } \\
\text { shoots }\end{array}$ & [25] \\
\hline
\end{tabular}


Table 1. Cont

\begin{tabular}{|c|c|c|c|c|c|}
\hline Crop & Microbe & Type of microbe & Tissue & Impact & Reference \\
\hline Potato & Glomus irregulare & Arbuscular mycorrhizal fungus & $\begin{array}{l}\text { Roots and } \\
\text { tubers }\end{array}$ & $\begin{array}{l}\text { Controlled the growth of Fusarium } \\
\text { sambucinum and inhibited the production } \\
\text { of the mycotoxin trichothecene } 4, \\
\text { 15-diacetoxyscirpenol }\end{array}$ & [26] \\
\hline \multirow{4}{*}{ Rice } & Bacillus sp. SH-10 and B. cereus SH-17 & Rhizospheric bacteria & Grain & $\begin{array}{l}\text { Increased } \mathrm{Zn} \text { concentration in grain (to } \sim 31 \\
\text { from } \sim 18 \mathrm{mg} \mathrm{kg}^{-1} \text { in control) }\end{array}$ & [27] \\
\hline & Cyanobacteria-based inoculants & Rhizospheric bacteria & Grain & $\begin{array}{l}13 \%-46 \% \text { enhancement in iron and } \\
15 \%-41 \% \text { enhancement in zinc }\end{array}$ & [28] \\
\hline & Enterobacter sp. ScCS20 & Rhizospheric bacterium & Grain & Improved $\mathrm{Zn}$ level & [29] \\
\hline & Sphingomonas sp. SaMR12 & Rhizospheric bacterium & Grain & Improved $\mathrm{Zn}$ level & [29] \\
\hline $\begin{array}{l}\text { Rice-wheat } \\
\text { cropping } \\
\text { system }\end{array}$ & $\begin{array}{c}\text { Anabaena oscillarioides, Brevundimonas diminuta, and } \\
\text { Ochrobactrum anthropi }\end{array}$ & Rhizospheric bacteria & Grain & $\begin{array}{l}\text { Micronutrient enrichment: } \mathrm{Fe}, \mathrm{Zn} \text { in rice, } \\
\text { and } \mathrm{Cu}, \mathrm{Mn} \text { in wheat. Increased N-P-K } \\
\text { contents and improved rice yield by } 21.2 \% \\
\text { (compared to using the recommended } \\
\text { dosage of chemical fertilizers) }\end{array}$ & [30] \\
\hline \multirow[t]{2}{*}{ Safed musli } & $\begin{array}{l}\text { Glomus fasciculatum, Glomus intraradices, or Glomus } \\
\text { mosseae }\end{array}$ & Arbuscular mycorrhizal fungi & Tuber & $\begin{array}{l}\text { Improved saponin level and improved } \\
\text { biomass of roots and shoots }\end{array}$ & [31] \\
\hline & Piriformospora indica and Pseudomonas fluorescens & $\begin{array}{l}\text { Arbuscular mycorrhizal fungus } \\
\text { and rhizospheric bacterium } \\
\text { respectively }\end{array}$ & $\begin{array}{l}\text { Micropropagated } \\
\text { plants } \\
\end{array}$ & $\begin{array}{l}\text { P. indica enhanced the level of saponin in } \\
\text { the plants. The co-inoculation of } P \text {. indica } \\
\text { and P. fluorescens further enhanced the } \\
\text { saponin level and also the contents of } \\
\text { micronutrients including } \mathrm{Fe}, \mathrm{Zn} \text {, and Mn. }\end{array}$ & [32] \\
\hline Snap bean & Rhizobium etli and Glomus intraradices & $\begin{array}{l}\text { Rhizospheric bacterium and } \\
\text { arbuscular mycorrhizal fungus }\end{array}$ & Seed & $\begin{array}{l}\text { Increased yield, number of snap beans, and } \\
\text { percentage of protein after } \mathrm{N} \text { fertilization }\end{array}$ & [33] \\
\hline Spinach & $\begin{array}{c}\text { Glomus fasciculatum, Glomus mosseae, N-fixer } \\
\text { (Azotobacter chroococcum), K solubilizer (Bacillus } \\
\text { mucilaginous), and P solubilizer (Bacillus megaterium) }\end{array}$ & $\begin{array}{l}\text { Arbuscular mycorrhizal fungi } \\
\text { and rhizospheric bacteria }\end{array}$ & Leaf & $\begin{array}{l}\text { Augmented the concentrations of total } \\
\text { phenolic compounds, flavonoids, and } \\
\text { phenolic acids }\end{array}$ & [34] \\
\hline
\end{tabular}


Table 1. Cont

\begin{tabular}{|c|c|c|c|c|c|}
\hline Crop & Microbe & Type of microbe & Tissue & Impact & Reference \\
\hline \multirow{5}{*}{ Strawberry } & $\begin{array}{l}\text { Rhizophagus intraradices, Glomus aggregatum, Glomus } \\
\text { viscosum, Claroideoglomus etunicatum, and } \\
\text { Claroideoglomus claroideum, and Pseudomonas fluorescens } \\
\text { strain Pf4 (Pf4) and Pseudomonas sp. 5Vm1K (5Vm1K) }\end{array}$ & $\begin{array}{l}\text { Arbuscular mycorrhizal fungi } \\
\text { and Rhizospheric bacteria }\end{array}$ & Fruit & $\begin{array}{l}\text { Co-inoculation increased fruit production, } \\
\text { fruit size, and concentrations of sugars and } \\
\text { ascorbic and folic acids }\end{array}$ & [35] \\
\hline & Phyllobacterium endophyticum PEPV15 & Rhizospheric bacterium & Fruit & Improved vitamin $C$ level and yield & [36] \\
\hline & Paenibacillus polymyxa RC05 & Rhizospheric bacterium & Fruit & Improved vitamin $C$ level and yield & [37] \\
\hline & Bacillus simplex $\mathrm{RC} 19$ & Rhizospheric bacterium & Fruit & Improved vitamin $C$ level and yield & [38] \\
\hline & Pseudomonas sp. $5 \mathrm{Vm} 1 \mathrm{~K}$ & Rhizospheric bacterium & Fruit & Improved vitamin $C$ level & [35] \\
\hline \multirow[t]{3}{*}{ Tomato } & Rhizophagus irregularis, Funneliformis mosseae & Arbuscular mycorrhizal fungus & Fruit & $\begin{array}{l}\text { Increased } \mathrm{N}, \mathrm{P} \text {, and } \mathrm{Cu} \text { concentrations, } \\
\text { higher antioxidant concentrations and } \\
\text { carotenoid contents }\end{array}$ & [39] \\
\hline & Pseudomonas sp. 19Fv1T & Rhizospheric bacterium & Fruit & $\begin{array}{l}\text { Improved vitamin } \mathrm{C} \text { level and fructose } \\
\text { level }\end{array}$ & [38] \\
\hline & Bacillus licheniformis & Rhizospheric bacterium & Fruit & Improved flavonoid level & [40] \\
\hline \multirow{5}{*}{ Wheat } & $\begin{array}{l}\text { Pseudomonas jessenii (R62) and Pseudomonas synxantha } \\
\text { (R81) and AMF consortium (Mnat) and (Mss2) }\end{array}$ & $\begin{array}{l}\text { Rhizospheric bacteria and } \\
\text { arbuscular mycorrhizal fungi }\end{array}$ & Grain & Significantly improved selenium content & [41] \\
\hline & $\begin{array}{l}\text { Pseudomonas strain (Providencia sp. PW5) and } \\
\text { Anabaena sp., Calothrix sp. and Anabaena sp. }\end{array}$ & $\begin{array}{l}\text { Rhizospheric bacteria and } \\
\text { arbuscular mycorrhizal fungi }\end{array}$ & Grain & $\begin{array}{l}\text { increased wheat yield and mineral nutrient } \\
\text { concentrations of } \mathrm{P}, \mathrm{K}, \mathrm{Cu}, \mathrm{Fe}, \mathrm{Zn} \text {, and } \mathrm{Mn}\end{array}$ & [41] \\
\hline & $\begin{array}{l}\text { Providencia sp. combined with } \mathrm{N}_{60} \mathrm{P}_{60} \mathrm{~K}_{60} \text { chemical } \\
\text { fertilizer }\end{array}$ & Rhizospheric bacterium & Grain & $\begin{array}{l}\text { Increases grain } \mathrm{Zn} \text { accumulation to } \sim 42 \mathrm{mg} \\
\mathrm{kg}^{-1} \text { compared to } 31.60 \mathrm{mg} \mathrm{kg}^{-1} \text { in control, } \\
\text { along with a three-fold increase in the } \\
\text { concentration of Fe. }\end{array}$ & [42] \\
\hline & Bacillus cereus YAP6 and Bacillus licheniformis YAP7 & Rhizospheric bacteria & Grain & $\begin{array}{l}\text { Increased Se concentrations in the grain by } \\
\text { up to } 375 \%\end{array}$ & [43] \\
\hline & $\begin{array}{l}\text { Eight AMF species } \\
\text { (Gigaspora margarita, } \\
\text { Funneliformis mosseae, } \\
\text { Rhizophagus irregulare, } \\
\text { Glomus clarum, } \\
\text { Glomus deserticola, } \\
\text { Glomus monosporum, } \\
\text { Glomus brasilianum, } \\
\text { Glomus aggregatum) }\end{array}$ & Arbuscular mycorrhizal fungus & Root & $\begin{array}{l}\text { increased the uptake of } \mathrm{P}, \mathrm{Fe} \text {, and } \mathrm{Zn} \text { with } \\
\text { improved root lengths and density }\end{array}$ & [44] \\
\hline
\end{tabular}


Table 1. Cont.

\begin{tabular}{|c|c|c|c|c|c|}
\hline Crop & Microbe & Type of microbe & Tissue & Impact & Reference \\
\hline & Glomus clarideum and Pseudomonas sp. R8 & $\begin{array}{l}\text { Arbuscular mycorrhizal fungus } \\
\text { and rhizospheric bacterium, } \\
\text { respectively }\end{array}$ & Grain & Improved selenium level & [45] \\
\hline & Glomus clarideum and Bacillus sp. R12 & $\begin{array}{l}\text { Arbuscular mycorrhizal fungus } \\
\text { and rhizospheric bacterium, } \\
\text { respectively }\end{array}$ & Grain & Improved selenium level & [45] \\
\hline
\end{tabular}




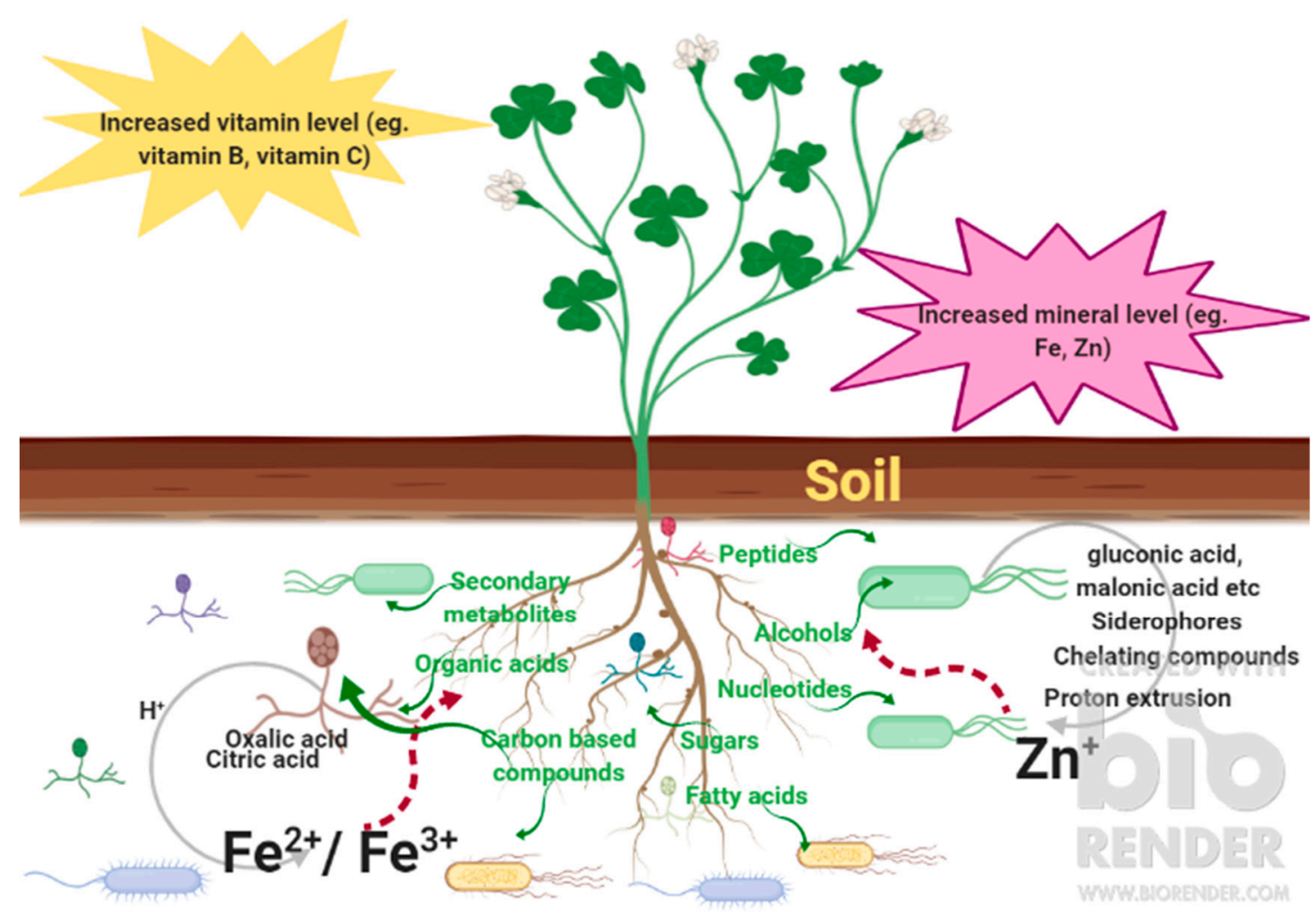

Figure 1. The complex interactions between plants and microbes in the soil bring about microbe-mediated biofortification. This figure is generated by BioRender.

\section{Common Dietary Deficiencies in Minerals and Vitamins and the Corresponding Biofortification Strategies}

\subsection{High Iron ( $F e)$ Acquisition Can Be Achieved through Soil Microbes}

Iron $(\mathrm{Fe})$ deficiency is regarded as the most common type of micronutrient deficiency in the human diet [3]. For plant growth, a wide variety of cellular processes such as chloroplast development, oxygen transport, chlorophyll biosynthesis, and mitochondrial functions are dependent upon the bioavailability of Fe in soils $[46,47]$. In many crops, the deficiency of Fe in soil leads to chlorosis which results in low-quality agricultural produce and poor yield [48]. Fe deficiency in plants is also closely related to the prevalence of Fe deficiency-induced anemia in humans [5].

In general, lowering the soil $\mathrm{pH}$, decreasing clay contents, increasing organic matter, improving drainage, and decreasing the excessive usage of phosphatic fertilizers can improve Fe uptake in plants. The acidification of the rhizosphere surrounding the roots of legumes and the extrusion of mugineic acid-family phytosiderophores via efflux transporters in non-leguminous plants are the two innate mechanisms in plants to overcome limitations in Fe availability in soil $[46,49,50]$. However, several studies have indicated that these strategies alone are insufficient to prevent plants from suffering from Fe deficiency in Fe-limiting soils. Sunflower and red clover crops had decreased Fe acquisition when grown in sterile soil versus in non-sterile soil, providing evidence that soil microbial activities probably played a critical role in Fe acquisition in plants [51]. A high Fe uptake was observed in wheat, white lupin, and cucumber plants upon the inoculation of a fungus, Trichoderma asperellum strain T34, in the soil [52]. In fungi, a variety of Fe uptake mechanisms have been reported, including those for free Fe ions, low-affinity Fe chelates, siderophore-Fe chelates, transferrin, heme, and hemoglobin [53]. Many microorganisms synthesize and release siderophores to overcome low Fe availability in aerobic calcareous soils [54]. Over 500 siderophores have been identified based on their ligand architectures, being in the form of hydroxamate, catecholate, or hydroxycarboxylic acid [55]. The solubilizing effect 
of siderophores on Fe hydroxides and their production in the rhizosphere have been proposed as a key microbial activity that benefits plants in enhancing Fe acquisition [48,51]. A high dissolution rate of insoluble Fe sources in the phenolic root exudates of Fe-deficient red clover plants was observed upon the addition of siderophores secreted by a Pseudomonas sp. [48]. These data indicate that Fe-siderophores may be incorporated into the roots of leguminous plants more efficiently than other Fe sources [47]. In maize, YS1 (Yellow Strip 1) has been suggested to be a Fe (III)-phytosiderophore transporter and its genetic transformation into yeast led to high iron uptake and restored normal growth [56].

A very old study indicated that each unit increase in soil $\mathrm{pH}$ decreases the availability of Fe up to 1000-fold [57]. The acidification of the rhizosphere via nitrification of ammonia and ammonium-based fertilizers can have an enormous positive impact on Fe availability. Soil nitrification is also catalyzed by ammonia-oxidizing prokaryotes [58]. In calcareous soils, many phosphate-solubilizing bacteria, including Penicillium bilaji and Penicillium cf. fuscum, significantly lower the soil $\mathrm{pH}$ in the presence of ammonium by excreting $\mathrm{H}^{+}$, which ultimately improves Fe solubility [59].

Besides these phosphate-solubilizing bacteria, a soil bacterium, Bacillus subtilis (GB03), could enhance Fe acquisition in Arabidopsis thaliana (A. thaliana) plants by activating its Fe deficiency-inducible responses, suggesting that soil micro-organisms could regulate plant Fe acquisition via signaling processes [60]. Recently the inoculation of Fe-tolerant bacterial strains, Bacillus toyonensis (MG430287), Rhodococcus hoagii (MG432495), Lysinibacillus mangiferihumi (MG432492), and Lysinibacillus fusiformis (MG430290) improved the growth and biomass of Brassica juncea by increasing the Fe contents in root, stem, and leaf compared to uninoculated plants [16]. Several phytohormones including auxin [61,62] nitric oxide (NO) [63], ethylene [64], cytokinin [65], and brassinosteroids [66] were also found to trigger Fe-deficiency responses in plant roots. Among these, auxin, NO and ethylene are particularly interesting due to their potential involvement in high Fe uptake by plants in the presence of soil microbes [47]. Like plants, some soil microbes also produce auxin-like compounds, such as indole-3-acetic acid (IAA), indole-3-butyric acid (IBA), indole-3-ethanol, indole-3-carboxylic acid, and indole-3-aldehyde, but the mechanisms of the involvement of these compounds remain unclear [67]. However, the ratio of auxin-producing micro-organisms in soil solution incubated with the phenolic root exudates of Fe-deficient red clover is higher than in phenolic-free samples [51,61]. In addition to auxin-like compounds, soil micro-organisms also produce NO through the processes of nitrification and denitrification [68]. The soil water content determines whether nitrification or denitrification is the dominant process in the soil, which in turn controls NO generation in the rhizosphere by soil microbes. Like auxin, $\mathrm{NO}$ acts as a catalyst in the regulation of Fe deficiency-inducible responses. The exogenous addition of the NO donor (S-nitrosoglutathione) promotes the reduction of $\mathrm{Fe}$ and the development of root hairs and lateral roots $[62,69,70]$. Therefore, it is reasonable to assume that NO generation by soil micro-organisms may enhance Fe acquisition of plants grown in Fe-limiting soils [47]. Some of the soil microorganisms also produce ethylene in the rhizosphere [71]. The exogenously-applied ethylene precursor (1-aminocyclopropane-1-carboxylic acid) significantly increased the reduction of Fe and root hair development, indicating that ethylene alters the microbial activities which could ultimately improve Fe acquisition by plants in Fe-limiting soils [64,72].

In leguminous plants, nodulation is a ubiquitous process for $\mathrm{N}_{2}$ fixation in which Fe-containing proteins play very important roles [73]. Thus, legumes have a higher need for Fe compared to non-leguminous plants. Common bean (Phaseolus vulgaris) under Fe limitation showed an over-accumulation of $\mathrm{H}^{+}$-ATPase and $\mathrm{Fe}^{2+}$ transport protein (IRT1) around the cortical cells of the root nodules [74]. The high Fe contents in pea (Pisum sativum L.) and lentil (Lens culinaris L.) upon nodulation of the roots by Rhizobium leguminosarum-PR1 indicate that nodulation can systemically improve the Fe nutrition of plants $[75,76]$. The increased secretion of phenolic compounds from leguminous plant roots in Fe-deficient soils favors the growth of nodulating rhizobia in legumes. Thus, nodulation can be another strategy for Fe acquisition by legumes via the secretion of phenolic compound into the rhizosphere. Some of the rhizobial strains produce siderophores under Fe-deficient 
conditions, which ultimately promote the synthesis of Fe-binding proteins by the plant for successful nodulation in legumes [73]. Hence, siderophore-producing rhizobia could be potential candidates for enhancing Fe acquisition, especially in legumes.

\subsection{Zinc (Zn) Deficiency Can Be Eradicated Using Soil Microbes}

Zinc $(\mathrm{Zn})$ is one of the most vital elements for all living organisms on Earth and its deficiency can lead to severe consequences. Zn deficiency affects more than $30 \%$ of the world's human population and it causes growth retardation, impaired immune functions, skin problems, loss of appetite, hair loss, diarrhea, delayed sexual maturation, impotence, and hypogonadism in males [77,78]. In plants, Zn deficiency leads to chlorosis, retarded shoot growth, decreased leaf size, susceptibility to biotic and abiotic stresses, poor grain yield, improper pollen and root development, as well as decreased water uptake and transport $[79,80]$. $\mathrm{Zn}$ availability is a global issue, as nearly $50 \%$ of the soils used for cereal cultivation contain very little bioavailable $\mathrm{Zn}$ [81]. Soils with less than $0.5 \mathrm{mg} \mathrm{kg}^{-1}$ DTPA (diethylene triamine penta-acetic acid)-extractable $\mathrm{Zn}$ are commonly considered to contain too little bioavailable $\mathrm{Zn}$ for optimal crop growth [82]. More than $50 \%$ of the agricultural soils in India and Pakistan are $\mathrm{Zn}$-deficient [83]. Physical properties, such as $\mathrm{pH}$, percentage of organic matter, water and clay contents, soil texture, and soil microbes, are the most critical factors that determine the bioavailability of $\mathrm{Zn}$ in soils [84]. Sandy soil and calcareous soil are the most $\mathrm{Zn}$-deficient soil types, whereas clay soil retains more $\mathrm{Zn}$ due to its high water-holding capacity. Heavy rain or flooding can lead to significant loss of bioavailable $\mathrm{Zn}$ in soils due to leaching and changing of the soil $\mathrm{pH}$. On the other hand, increasing organic matter can improve Zn solubility and availability by decreasing its binding to other soil elements. Externally applied $\mathrm{Zn}$ in the form of fertilizer can also be fixed with manganese (Mn) and Fe hydroxides on soil colloids [79].

Both bacteria and fungi have been found to enhance $\mathrm{Zn}$ solubility in the rhizosphere. The bacterial genera, Azotobacter, Azospirillum, Bacillus, Gluconacetobacter, and Pseudomonas, have all been identified as $\mathrm{Zn}$ solubilizers [85]. Arbuscular mycorrhizae and the genus Trichoderma are the two groups of fungi possessing Zn-solubilizing activities in soil [86]. By inoculating these microbial strains into the soil where the crops are grown, not only will the bioavailability of $\mathrm{Zn}$ be improved, but we can also promote a sustainable agro-ecosystem. Through the siderophore and exopolysaccharide production, nutrient solubilization, the production of organic acids and phytohormones, the mobilization of nutrients, and the fixation of atmospheric nitrogen carried out by these microbes, the availability of $\mathrm{Zn}$ can be raised, thus helping plants to uptake more $\mathrm{Zn}$ from the soil [87]. Significant increases in $\mathrm{Zn}$ contents in maize grains were observed when the crop was grown in soil inoculated with the bacterial strains from the genera Azotobacter, Pseudomonas, Bacillus, and Azospirillum [88,89]. In rice, following the inoculation with bacterial and endophytic strains (Azospirillum lipoferum [JCM-1270, ER-20], Pseudomonas sp. [K-1, 96-51], Agrobacterium sp. [Ca-18], Sphingomonas sp. [SaMR12], and Enterobacter sp. [SaCS20]), the bioavailability of $\mathrm{Zn}$ in the soil was significantly enhanced, resulting in higher levels of $\mathrm{Zn}$ in the grains and the yields were also improved [29,90,91]. In soybean and wheat, an increase in the mobilization of $\mathrm{Zn}$ and its concentrations in the edible portions were observed following the inoculation of the soil with Bacillus aryabhattai strains (MDSR7, MDSR11, and MDSR14) [92]. The two newly identified bacterial strains (FA-9 and FA-11) from the wheat rhizosphere, belonging to the species Pseudomonas aeruginosa and Enterobacter sp., possess a great potential to solubilize $\mathrm{Zn}$ from $\mathrm{Zn}$ carbonate in a liquid medium, along with carrying out various rhizospheric activities such as the production of exo-polysaccharides and siderophores, P solubilization, ACC (1-aminocyclopropane-1-carboxylic acid) deaminase, and antifungal activities [93]. Particularly in wheat, the inoculation of Providencia sp. (PW5), Anabaena sp. (CW1), Calothrix sp. (CW2), and Anabaena sp. (CW3) did not only increase the $\mathrm{Zn}$ contents in grains but also improved the protein contents and other micronutrients such as $\mathrm{Fe}, \mathrm{Cu}$, and $\mathrm{Mn}$ [42]. Recently, the discovery of $\mathrm{Zn}$ nanoparticles from the cell-free culture filtrates of Pseudomonas, Bacillus, and Azospirillum strains suggests that these microbes may solubilize Zn by producing nanoparticles to mobilize nutrients in the rhizosphere [94]. Eight strains from the genera 
Curtobacterium, Plantibacter, Pseudomonas, Stenotrophomonas, and Streptomyces have been successfully identified from the wheat rhizosphere to be highly efficient in $\mathrm{Zn}$ solubilization as well as siderophore production [95]. A high level of mobilization of $\mathrm{Cu}$ and $\mathrm{Zn}$ was observed in spinach (Spinacia oleracea L.) and tomato (Lycopersicon esculentum L.), which indicates that the release of organic ligands improves the solubility of trace elements in soil. On the other hand, the insufficient release of citrate and malate compounds by rice plants growing in $\mathrm{Zn}$-deficient soil shows that the effectiveness of a specific exudate is likely to vary in different soil types $[96,97]$. The success of these inoculated strains depends upon their ability to colonize, survive and mobilize trace elements in the rhizosphere under natural conditions. It is necessary to understand the molecular mechanisms behind $\mathrm{Zn}$ solubilization by these bacteria before planning to use them as inoculants. However, despite various potential applications of $\mathrm{Zn}$-solubilizing bacteria, few studies have focused in detail on the underlying mechanisms of solubilization.

$\mathrm{Zn}$-solubilizing bacteria improve $\mathrm{Zn}$ bioavailability in soil through various mechanisms of action [83]. In general, reducing the soil $\mathrm{pH}$ is the key to unlocking many micro- and macro-nutrients in the rhizosphere. A one-unit decrease in soil pH can improve $\mathrm{Zn}$ availability 100 times [98]. These bacteria achieve this by the release of organic acids and thus protons into the rhizosphere [99]. For example, the secretion of 2-ketogluconic acid and gluconic acid by Pseudomonas fluorescens solubilizes Zn phosphate in the liquid culture [100]. Similarly, a change in $\mathrm{pH}$ of the liquid culture was observed upon the co-inoculation of Pseudomonas and Bacillus species, which solubilized the Zn-containing complexes in that culture [101]. It is important to mention that $\mathrm{Zn}$-solubilizing bacteria do not rely on only one strategy to solubilize the trace elements. Instead, the mechanism employed changes depending on the situation. For example, the presence of glucose in the liquid medium stimulated organic acid (such as gluconic, malonic, and oxalic acid) production by eight $\mathrm{Zn}$-solubilizing bacterial strains [95], leading to the acidification of the medium and subsequent $\mathrm{ZnO}$ solubilization. In contrast, in the absence of glucose, $\mathrm{ZnO}$ dissolution resulted from proton extrusion (e.g., via ammonia consumption by Plantibacter strains) and complexation processes (e.g., complexation with glutamic acid in the culture of Curtobacterium sp.). Bacteria are not the only organisms that can secrete organic acids, but some of the arbuscular mycorrhizal fungi could also solubilize Zn phosphate by secreting organic acids into the rhizosphere as well [102]. A decrease in rhizospheric soil $\mathrm{pH}$ upon the inoculation of arbuscular mycorrhizae contributed to the release of $\mathrm{Zn}$ from the mineral fraction [103]. However, the degree of reduction in soil $\mathrm{pH}$ depends upon many factors such as the type of soil, soil texture, geographic location, and its associated soil microbial communities. The high reactivity and low persistency of $\mathrm{Zn}$ in soil result in the formation of $\mathrm{Zn}$-metal complexes that hinders its availability to plants. Naturally existing and synthetic $\mathrm{Zn}$-chelating compounds also have the potential to enhance $\mathrm{Zn}$ bioavailability in the rhizosphere [104]. Chelation is also a dominant mechanism used by many Zn-solubilizing bacteria, such as Pseudomonas monteilii, Microbacterium saperdae, and Enterobacter cancerogenus, to make chelating metallophores which increase the concentration of water-soluble $\mathrm{Zn}$ in the soil for uptake by plants [105]. A biofertilizer containing Pseudomonas sp. (96-51), Azospirillum lipoferum (JCM-1270, ER-20), and Agrobacterium sp. (Ca-18) increased Zn bioavailability for longer periods in the soil by releasing ethylenediamine-tetraacetic acid (EDTA) as the chelating agent [91]. $\mathrm{Zn}$ is an immobile element in the soil and expanding the root surface area could be another strategy to increase $\mathrm{Zn}$ availability. The association of mycorrhizal fungi with roots can increase the surface area of the root, helping plants to take up more $\mathrm{Zn}$ from the surrounding soil. An increase of up to $4 \%$ in $\mathrm{Zn}$ in the grains was observed in plants as a result of the association with mycorrhizal fungi [103].

\subsection{Vitamins Are Popular Targets of Biofortification}

Golden Rice has been a golden example of biofortification of provitamin A. In 2016, scientists who developed the orange-fleshed sweet potato to combat vitamin A deficiency were recognized by the World Food Prize [106]. Current methods of improving the provitamin A contents in crops include breeding and transgenic approaches [107]. Taking Golden Rice as an example, having a gene from daffodil (Narcissus pseudonarcissus) and a bacterial gene from Erwinia uredovora introduced into rice 
through transgenic approaches allows Golden Rice to start synthesizing $\beta$-carotene [108]. Because many crops cannot produce $\beta$-carotene natively, the immense capital investment and technical know-how required to produce transgenics capable of synthesizing $\beta$-carotene in each of these crops severely limit the scope of this approach to biofortification. The arduous approval process for transgenic crops to be sold on the market is also a significant hurdle. It took 18 years after the initial publication of the research on Golden Rice before it was finally approved by the U.S. Food and Drug Administration in 2018 [109]. Hence investigating ways of biofortification of provitamin A contents in crops using microbes remains a wide-open and much-needed area for research.

The B vitamins and vitamin C can be synthesized in numerous food crops. The pathways of B vitamins and vitamin C biosynthesis are well-studied $[110,111]$. The enrichment of vitamins $B$ and $C$ contents in food crops has been a focus of biofortification. It has been shown that plants can take up vitamins $B_{1}$ (thiamine) and $B_{12}$ (cobalamin) from soil [112]. Although plants can synthesize vitamin $B_{1}$, the contents of vitamin $B_{1}$ in staple crops are generally low. Therefore, the deficiency in vitamin $B_{1}$ is a common problem in areas where human diets consist overwhelmingly of staple crops. There have been attempts to improve the vitamin $B_{1}$ levels in crops using the transgenic approach. However, it is only recently that the challenge has been overcome $[113,114]$. The first example of vitamin $B_{1}$ biofortification in staple crops using transgenics was reported in 2016 [115]. The overexpression of 4-methyl-5- $\beta$-hydroxyethylthiazole phosphate synthase and 4-amino-2-methyl5-hydroxymethylpyrimidine phosphate synthase, which are involved in the synthesis of thiazole and pyrimidine, respectively, led to the increase in the thiamine content of unpolished rice grains [115]. As early as the 1950s, it was found that fodder plants irrigated with sewage water had higher vitamin $B_{1}$ contents than those irrigated with clean water [116]. Later, it was found that spinach grown organically had a higher vitamin $B_{1}$ content than that grown by conventional methods [117]. Similarly, for green gram and wheat, it was found that the application of cow dung or cane-bagasse in the fields could improve the vitamin $B_{1}$ contents of the plants [118]. These findings hinted at the role of microbes in improving the vitamin $B_{1}$ levels in plants. In 2017, a detailed study on the microbe-mediated biofortification of vitamin $B_{1}$ was first to report on the improvement of thiamine biosynthesis in oil palm seedlings by the introduction of Hendersonia toruloidea, an endophytic fungus that colonizes the cortical cells of the oil palm root [21,22]. Oil palms inoculated with $H$. toruloidea showed increased expressions of key thiamine biosynthesis genes including THI4, THIC, TH1, and TPK for 30 days after the inoculation until they were downregulated [21,22]. Consequently $H$. toruloidea-inoculated oil palms showed improved vitamin $B_{1}$ accumulation in the leaves [21,22].

Among the eight $B$ vitamins, vitamin $B_{12}$ is unique as it is synthesized by microorganisms but not by plants. Barley and spinach treated with pure vitamin $B_{12}$ or cow dung showed increased vitamin $B_{12}$ levels in the seeds and leaves, respectively [112]. The uptake of vitamin $B_{12}$ by soybean roots in a vitamin $B_{12}$-supplemented nutrient solution was also reported [119]. As early as the 1950s, it was found that the vitamin $B_{12}$ content in turnip greens was geography-dependent [120]. It was then speculated that vitamin $B_{12}$ might have originated from microbes [121]. By adding cow dung to soil to increase the vitamin $B_{12}$ level in spinach leaves, the microbial origin of vitamin $B_{12}$ was confirmed [119]. Due to the lack of vitamin $B_{12}$ synthesis genes, crops cannot innately produce vitamin $B_{12}$. However, as demonstrated previously, plants can take up vitamin $B_{12}$ from the surrounding soil and transport it to the edible parts. Therefore, the application of vitamin $B_{12}$-synthesizing bacteria to the soil for growing crops could be a way to improve the vitamin $B_{12}$ contents of crops. Compared to the current practice of applying vitamin $B_{12}$-containing chemical fertilizers, this could be a "greener" alternative. Although many processed crop products, such as wheat flour, are routinely fortified with vitamins during production [122], fortifying growing crops with vitamin $B_{12}$ using the microbe-mediated approach has, up to now, been rarely done.

Fruits are major sources of vitamin $C$ in the human diet. As a result, fruits have been major targets of biofortification with vitamin C [123]. Common approaches of vitamin C biofortification include the application of fertilizers, the breeding of elite germplasms, and metabolic engineering $[123,124]$. 
For example, the overexpression of SIGME1 or SlGME2 enhanced ascorbate accumulations in the leaves and ripe fruits of tomato [125]. Besides the improved ascorbate accumulation, the transgenic plants were also found to have improved tolerance to oxidative stress, cold stress, and salt stress [125]. Both bacteria and fungi were also found to enhance vitamin $C$ levels when inoculated into/onto the plants $[126,127]$. Strawberry and tomato have been the popular targets for vitamin C biofortification using microbe-mediated approaches [126]. The improvement of vitamin C content is usually accompanied by the improvement of other agronomic traits. For instance, the inoculation of Phyllobacterium endophyticum strain PEPV15, Paenibacillus polymyxa RC05 isolated from barley, and Bacillus simplex RC19 isolated from wild raspberry improved the vitamin C contents in the fruits of strawberries and also the yields [36,37], and the inoculation of Pseudomonas sp. 19Fv1T to the soil used to grow tomato plants enhanced both the vitamin $C$ and the fructose levels of the fruit [38]. The inoculation of Pseudomonas sp. $5 \mathrm{Vm} 1 \mathrm{~K}$ to the media used to grow strawberry plants improved the vitamin C, glucose, and fructose levels in the fruit [35]. The inoculation of Glomus fasciculatum or a commercial inoculum consisting of Glomus intraradices (Schenck and Smith) and Glomus mosseae (Nicol. and Gerd.) Gerd. and Trappe to the growth medium of lettuce improved the ascorbate level as well as the fresh weight of the leaves [20]. Inoculation of blue-green algae has been used as a measure to improve crop yield. However, it was found that the inoculation of blue-green algae, as in a mixture of Tolypothrix tenuis, Aulosira fertilissima, Nostoc sp. Anabaena sp., and Plectonema boryanum, to tomato improved the yield but not the vitamin $C$ level in the fruit [128]. In some cases, the inoculation of microbes negatively affected the fruit vitamin $C$ content $[38,129]$. For example, the inoculation of a mixture of plant growth-promoting rhizobacteria (PGPR), consisting of Pseudomonas BA-8 (a biological control agent), Bacillus OSU-142 ( $\mathrm{N}_{2}$-fixing), and Bacillus M-3 ( $\mathrm{N}_{2}$-fixing and phosphate-solubilizing), had a negative impact on the fruit vitamin $C$ level of strawberry [129]. Therefore, microbe-mediated biofortification of vitamin $\mathrm{C}$ has the potential to bring forth great benefits but more studies are required to fully understand the underlying mechanisms in order to reap the full benefit of this approach.

\section{Microbes Enhance the Level of Beneficial Secondary Metabolites}

In under-developed regions, there is a need to fortify crops to ensure that sufficient essential micronutrients can be obtained from the diet. In wealthy societies, biofortification of crops could be a way to let humans obtain non-essential health supplements. There are limited examples of flavonoid and saponin biofortification. Detailed mechanisms of how the microbes mediate the biofortification of flavonoids and saponins are largely unknown. Nevertheless, the following examples illustrate the potential of microbes to be used for fortifying health supplements besides the aforementioned micronutrients.

\subsection{Flavonoids}

Flavonoids are a large group of secondary metabolites characterized by a 15-carbon skeleton and a polyphenol molecular structure [130]. The molecular structure of flavonoids contributes to their antioxidizing activities and hence the benefits to human health [131]. Unlike the above-discussed micronutrients which are regarded as essential, flavonoids are not considered essential nutrients, but the health benefits of flavonoids have widely drawn the public's attention in recent years [130]. Breeding and metabolic engineering are major strategies of flavonoid biofortification [132]. For example, the expressions of both $L C$ and $C 1$, which are transcription factors from maize, enhanced the levels of flavonols (a major group of flavonoids) in the flesh of the tomato fruit, which does not innately produce flavonoids [133]. Some reports have provided direct evidence of using microbe-mediated biofortification to improve flavonoid levels. It was found that the inoculation of Pseudomonas fluorescens N21.4 to blackberry plants increased the flavonoid levels of the fruit $[14,15]$, probably by upregulating the expressions of several flavonoid biosynthesis genes [15]. Additionally, the inoculation of Bacillus licheniformis to tomato plants, together with $75 \%$ of the recommended dosage for nitrogen fertilizer, improved the flavonoid levels in the fruit [40]. While it has been a concern that flavonoids are heat-labile 
and could be destroyed during the cooking process [134], the flavonoid-fortified tomato fruit, which can be, and often are, eaten raw, would be a good dietary source for these antioxidants.

\subsection{Saponins}

Saponins are a group of bitter-tasting compounds regarded as the active compounds responsible for the health benefits of foods such as soybean and garlic, as well as plants used in herbal medicine [135]. Their anticancer activities [136] and cholesterol-lowering abilities [136] have been suggested. Plants are the major sources of saponins in the human diet [135]. The enrichment in saponin levels in crops could be beneficial for human health. Not all plants are rich in saponins. However, it has been shown that transgenic methods could be used to improve the saponin levels in crops such as rice, which innately does not have high levels of saponins. The overexpression of a $\beta$-amyrin synthase gene from Panax japonicus led to the accumulation of ginsenoside, an oleanane-type saponin that is the bioactive compound in ginseng, in rice seeds [137]. Endophytic mycorrhizal fungi have been known to synthesize saponins. A few Fusarium spp. isolated from Panax ginseng were found to be able to produce ginsenosides [138]. Safed musli (Chlorophytum borivilianum) is a medicinal plant. It was found that the inoculation of endophytic fungi, either Glomus fasciculatum, Glomus intraradices, or Glomus mosseae, enhanced the saponin contents in the tubers of this plant as well as enhancing the biomass of both roots and shoots [31]. In another study on safed musli, both endophytic mycorrhizal fungus and rhizospheric bacterium were also found to have beneficial effects on its saponin levels. When the micropropagated plants of safed musli were inoculated with the endophytic mycorrhizal fungus, Piriformospora indica, it was found that the saponin contents were increased [32]. This beneficial effect was further enhanced when the plants were co-inoculated with both $P$. indica and the growth-promoting bacterium, Pseudomonas fluorescens [32]. The co-inoculation of P. indica and P. fluorescens also led to the increased contents of micronutrients including Fe, Zn, and Mn [32].

\section{Endophytes as the Emerging Participant of Microbe-Mediated Biofortification}

Literally, "endophyte" means "in the plant" [139]. Endophytes are generally known as non-pathogenic microbes that colonize inside plant tissues including roots [140]. For example, as mentioned above, $H$. toruloidea, is found to be an endophytic fungus of oil palm that colonizes the cortical cells of the oil palm root [21,22]. The beneficial effects of root endophytes on plant growth has been extensively discussed [139]. Besides plant growth, there is emerging evidence showing the involvement of endophytic fungi in biofortification. The symbiotic mechanism involves extensive interactions between plants and endophytes. Plants excrete metabolites to initiate the symbiosis with these fungi. For mycorrhizal symbiosis, the transport of fatty acids (linoleic, oleic, palmitic, and/or stearic acid) by ABCG (ATP-binding cassette transporter subfamily $\mathrm{G}$ ) proteins is essential because mycorrhizal fungi depend on their hosts for certain fatty acids [141,142]. One ABCG member, STR (stunted arbuscule), was previously shown to be required for mycorrhization [143]. Secondary metabolites such as coumarins (e.g., esculetin, esculin, scopoletin, scopolin, 4-methylumbelliferone), sterols (e.g., campesterol, cholesterol, sitosterol, stigmasterol), hormones, and glucosinolates are omnipresent in root exudates, and $A B C$ transporters are potentially responsible for their transport into the rhizosphere. Exudates of $A$. thaliana abcg37/pdr9 mutant lines were found to be deficient in several phenylpropanoids [144].

Endophytes can enhance the accumulation of nutrients including $\mathrm{Fe}, \mathrm{Zn}, \mathrm{B}$ vitamins, vitamin $\mathrm{C}$, flavonoids, and saponins. In addition, endophytes can also enhance the accumulation of nitrogen and minerals in crops. Since the adverse effects of nitrogen fertilizer on the environment has been well known [145], microbe-mediated biofortification could be a "greener" alternative to provide the crops with nitrogen. Legumes are famous for its ability to form nitrogen-fixing nodules with rhizobia. The rhizobium-mediated nitrogen fixation in the root nodules of legumes has been extensively reviewed [146,147]. For non-legume crops, it was reported that in one case, an increase in plant nitrogen acquisition was found to be dependent upon the synergies between mycorrhizal fungi and 
soil microbial communities [148]. Specifically, it has been reported that endophytic microbes can translocate nitrogen from insects to the host plant. By inoculating the endophytic fungus Metarhizium rebertsii into haricot bean and switchgrass, it was shown that $M$. rebertsii translocated nitrogen from waxmoth, the prey of M. rebertsii, to the host plant [149]. This endophyte-mediated non-soil origin of nitrogen for plants further expands the potential of microbe-mediated biofortification.

Apart from nitrogen, endophytes were found to improve the level of other minerals in crops. This helps reduce the use of chemical fertilizers. It was found that the inoculation of Bacillus subtilis DS-178 and Arthrobacter sp. SD-179 improved the level of $\mathrm{Zn}$ in the grains of wheat fertilized with the recommended dosage of an NPK fertilizer [150]. Besides, it was found that Enterobacter sp. ScCS20 and Sphinogomonas sp. SaMR12, which were isolated from the Zn-hyper-accumulator Sedum alfredii, were able to colonize rice roots, increasing the bioavailability of $\mathrm{Zn}$ in the rhizospheric soil and enhancing the level of $\mathrm{Zn}$ in the rice grains [29]. When wheat plants were co-inoculated with Glomus clarideum and either Pseudomonas sp. R8 or Bacillus sp. R12, the selenium level in the grains was improved compared to inoculating with either of the bacteria alone [45]. Besides, mycorrhizae also excrete $\mathrm{H}^{+}$and low-molecular weight organic chelating compounds, such as citric acid, oxalic acid, and siderophores, to solubilize Fe in soil [151]. Recently, mycorrhizal inoculation in wheat roots was reported to have increased the uptake of $\mathrm{P}, \mathrm{Fe}$, and $\mathrm{Zn}$ by the plant, along with greater root length and density [44]. In maize, the symbiosis of mycorrhiza alters the expression patterns of three key iron homeostasis genes in sulfur-deprived plants, which indicates sulfur works as a signaling molecule for Fe homeostasis $[152,153]$. The recent growing evidence on the beneficial effects of endophytes suggests that the current knowledge on endophytes could be only the tip of the iceberg.

\section{The Mechanisms of Microbe-Mediated Biofortification}

To summarize the above discussion, the mechanisms of how the nutrient levels in plants are improved by microbe-mediated biofortification can be categorized into three types.

\subsection{By Improving the Availability of Nutrients to Be Absorbed by Plants}

A lot of nutrients, such as minerals, are already present in the soil. However, the minerals may not be in the chemical forms that could be readily taken up by plants. One of the examples is Fe ions, which are usually present in hydroxide form in soil. Some microbes solubilize the hydroxide to free the Fe ions for the plants to import, whereas some other microbes, including mycorrhizal fungi [151] and growth-promoting bacteria [48], excrete small molecules (siderophores) to solubilize Fe in soil [151]. Besides mediating the availability of nutrients in soil, endophytic fungi have also been found to be able to mediate the transfer of nitrogen sources from insects to plants [149]. Besides, Azotobacter, Azospirillumm, Bacillus, Gluconacetobacter, and Pseudomonas, all genera of growth-promoting bacteria [85], and Trichoderma, a genus of fungi, have all been reported to exhibit $\mathrm{Zn}$-solubilizing activities in the soil [86].

\subsection{By Directly Synthesizing and Releasing Micronutrients Either in the Soil or as Endophytes}

Microbes are able to synthesize some important nutrients. For example, vitamin $B_{12}$ is synthesized by microbes but not by plants. Several endophytic fungi are able to synthesize saponins such as ginsenosides [138].

\subsection{By Inducing the Plants to Synthesize the Micronutrients}

In some cases, it was found that the inoculation of microbes induced the expression of micronutrient synthesis-related genes. For example, the inoculation of $H$. toruloidea into oil palms led to the higher expressions of THI4, THIC, TH1, and TPK, which are related to thiamine synthesis [21,22]. In blackberry, it was shown that the inoculation of $P$. fluorescens N21.4 led to the increased expressions of several flavonoid biosynthesis genes [15]. 


\section{How Root Exudates Help to Shape the Rhizobiome}

Plant health in natural environments relies on its interactions with a complicated and diverse group of macro- and micro-organisms. Plants can host up to 1000 distinct microbial species by supplying them with carbon sources via root exudation in the rhizosphere [154]. Twenty percent of the carbon fixed by photosynthesis is released into the rhizosphere, which works as a nutrient-clearing house for promoting successful plant-microbe interactions [155]. In turn, plant-associated microbiota improve plant growth by enhancing the bioavailability of nutrients such as $\mathrm{N}, \mathrm{P}$, and $\mathrm{K}$ to plants, as well as protecting plants against phytopathogens [156]. In addition to providing a source of carbon, plant roots also supply other metabolites that are more beneficial to some microbes than others [157]. Root-derived exudates mainly consist of sugars, alcohols, phosphates, amino acids, organic acids, nucleotides, peptides, fatty acids, and secondary metabolites [158]. Sugars constitute a significant proportion of exudates, and are a major source of carbon for microbes [159]. Sweet (sugars-will-eventually-be-exported transporters)-mutant plants showed higher sugar exports from roots than wild-type plants [160]. Until now, no sugar transporters directly involved in exporting sugars into the rhizosphere have been identified. The presence of higher sucrose concentrations around young and permeable root tissues, compared to older and less permeable ones, indicates that a passive sugar efflux mechanism may be involved in sugar transport in the rhizosphere [161]. A higher rate of release of glutamate, glucose, ribitol, citrate, of c-aminobutyric acid, and carbohydrates from Fe- and P-deficient plants suggests that these root exudates may be intended for attracting more microbes that can help with the release of nutrients from the soil. K-starved plants released less sugar, glycerol, ribitol, fructose, and maltose, while, under nitrogen deficiency, lower amounts of amino acids were found in root exudates [162]. Sugar alcohols including inositol, myo-inositol, threitol, xylitol, erythritol, and ribitol are also detected in exudates but their modes of export by plants are not well understood [158]. The involvement of sugar phosphates in plastid-localized sugar-phosphate transport and intracellular carbohydrate metabolism have been reported in several plant species [163]. Although sugar phosphates have been detected in exudates, their mechanisms of import and export remain unclear.

Amino acids make up an important fraction of exudates characteristic of the early stages of root colonization and are detected by microbial chemoreceptors [164]. The higher tryptophan exudation from older roots than younger ones [161] indicates that transporter proteins are involved in exudation. The variation in the concentrations of amino acids in root exudates and root extracts are not the same for all the amino acids, suggesting that at least some amino acids are selectively transported [165]. The secreted amino acids from the roots of ryegrass lowered the soil $\mathrm{pH}$ and increased the availability of free $\mathrm{Zn}$ in the soil [166]. Organic acids, such as succinic, malic, tartaric, lactic, formic, butyric, acetic, propionic, gluconic, oxalic, citric, pyruvic, malonic, $\alpha$-ketoglutaric, fumaric, trans-aconitic, aspartic, benzoic, and glyceric acid, make up a big portion of exudates and serve as microbial nutrients [158]. Aluminum-activated malate transporters (ALMTs) and the multidrug and toxic compound extrusion (MATE) family of transporters responsible for exporting malate and citrate are among the few well-understood examples of transporters involved in organic acid exudation [158]. These root exudates also improve the cation exchange capacity in the soil by providing ion exchange sites for $\mathrm{Zn}$ and other mineral elements [167]. Root exudates also include nucleotides (adenosine, guanosine, cytidine, thymine) and oligopeptides which are also actively imported by secondary transporters, but the mechanisms of their exudation remain unclear $[168,169]$.

It is also important to understand here that plant roots also secrete antimicrobial peptides that hinder microbial colonization as a result of immune responses, of which only a selected group of microbes are tolerant [170]. In maize, a change in the amount of exuded amino acids, sugars, and organic acids under potassium-deficient conditions indicates that exudations are also modulated by abiotic stresses [171]. Other examples include the increased exudation of coumarin and oligolignol by P-deficient $A$. thaliana plants, and increased organic acid exudation by Populus tremula under heavy metal stress, and increased phytosiderophore exudation by Zn-deficient wheat [172,173]. A report 
recently showed that exuded coumarin in response to Fe starvation reshaped the microbiome and could also protect the $A$. thaliana against the pathogenic fungi, Fusarium oxysporum and Verticillium dahliae [174]. In A. thaliana, the assembly of the root microbiome is highly influenced by MYB72 and BGLU42, which are involved in the biosynthesis and exudation of scopoletin (a coumarin) into the rhizosphere. Furthermore, this process is triggered by beneficial bacteria. Some of the beneficial root microbes also stimulate a defense mechanism in the plant known as induced systemic resistance against diseases caused by foliar pathogens [175]. Differential exudation is a plausible mechanism by which plants could modulate their interactions with microbes, as illustrated by the correlations between exudation patterns and rhizobiome variations reported for eight $A$. thaliana accessions [176].

The effect of plant genotype on rhizobiome composition was found to be similar between $A$. thaliana and barley (Hordeum vulgare) grown in the same experimental conditions with respect to the relative abundances and distributions of taxonomic groups of the microbes [177]. Intraspecific plant variations can prompt changes in the surrounding environment (soil conditions) and the compositions of underground microbiota, potentially inducing plant-soil feedback responses [178]. Interestingly, some species, such as maize and birdsfoot trefoil (Lotus japonicus), assembled a distinct rhizobiome, while other species, such as $A$. thaliana and rice, assembled a rhizobiome-like bulk soil [158]. The integrity of the rhizosphere differs according to the developmental stage of the plant $[179,180]$. Similarly, root exudation and microbial communities change with the age of the plant [179]. Various developmental phases of $A$. thaliana can be correlated to distinct rhizobiomes and similar results were identified in Avena fatua $[179,181]$ and in rice [182]. Moreover, crop duration was also discussed as a hypothesis for successive microbiomes [182]. Genetic variations in crops have an impact on root structure, composition, and exudates, and many studies have attempted to determine the extent of plant genetics as a determinant on its associated root microbiomes [183]. In general, these studies have shown that plant genotype affects the root microbiome, but it does not make as much a difference as soil composition does on the microbiome [170].

Previous studies have shown that the radial proximity and lateral position of microbes relative to the roots define the microbiome complexity and its composition $[181,184,185]$. The root structural components, which include root tips, root elongation and maturation zones, and lateral root number, are also responsible for determining a distinct microbial community that is different from another [184-187]. The root tip is the first component of the root that comes into direct contact with the microbiome. It produces border cells and mucilage, essential for interactions between plant and microbes [158]. The longevity of the border cells in soil is different for different plants. Individual border cells in maize remained alive in soil for months, probably due to the presence of starch deposits [188], whereas border-like A. thaliana cells survived for only two weeks [189]. Cluster roots formed under low $\mathrm{pH}$ are dominated by Burkholderia species that metabolize citrate and oxalate, while in nutrient-poor soils the roots exude high amounts of organic acids and protons to solubilize phosphates $[190,191]$. In addition to organic acid exudation, mature cluster roots also exude isoflavonoids and fungal cell wall-degrading enzymes, resulting in reduced bacterial abundance and fungal sporulation [192]. A recent review paper briefly addressed how root morphology shapes rhizobiomes in the rhizosphere [158].

Interactions between plants and microbes are not only dependent on root morphology and exudates, but they are also shaped by microbe-microbe interactions. Several studies have examined whether the diversity of plant exudates correlates with microbial diversity. Some studies discovered that higher plant exudate diversity was associated with higher microbial diversity [193,194], and the addition of a diverse exudate mix to plant monocultures increased microbial diversity [195]. In conclusion, the influence of environmental factors on microbial diversity was greater than that on plant diversity, and high plant diversity appears to promote a diverse microbial community [194]. However, it is still unclear whether microbe-microbe interactions are predominantly positive or negative within the rhizosphere [158], but some network analyses reported predominantly positive intra-kingdom interactions $[180,196]$. 


\section{Conclusions}

Threats to global food security and the current and future impacts of hidden hunger on modern life have been highlighted by many authors to date $[6,197]$. Undoubtedly modern breeding tools such as genetic modifications and metabolic engineering can combat hidden hunger effectively but they are often time-consuming, expensive, and encounter many regulatory obstacles regarding GMOs. As alternatives, rhizospheric and endophytic microbes can serve as cost-effective and sustainable solutions to overcoming hidden hunger. Microbes can be easily applied to the growing crops for biofortification purposes. Yet, the easily-applied microbe-mediated fortification involves complex interactions between plants and microbes in the soil. Such interactions are part of the dynamic process in which plants and microbes regulate one another's growth. Using examples from the literature, here we have highlighted the great potential for plant growth-promoting bacteria and mycorrhizal fungi to be applied as a sustainable and affordable alternative for crop biofortification.

Author Contributions: Y.-S.K. and H.M.R. compiled the materials and wrote the manuscript. H.-M.L. coordinated the writing effort and revised the manuscript.

Funding: This work was funded by Hong Kong Research Grants Council Area of Excellence Scheme (AoE/M-403/16), Lo Kwee-Seong Biomedical Research Fund, CUHK Vice Chancellor Discretionary Fund (Project Number: 4930735) and Virtual University Park Support Scheme to CUHK Shenzhen Research Institute (YFJGJS1.0).

Acknowledgments: This work was supported by Hong Kong Research Grants Council Area of Excellence Scheme (AoE/M-403/16), Lo Kwee-Seong Biomedical Research Fund, CUHK Vice Chancellor Discretionary Fund (Project Number: 4930735) and Virtual University Park Support Scheme to CUHK Shenzhen Research Institute (YFJGJS1.0). Jee Yan Chu copy-edited the manuscript.

Conflicts of Interest: The authors declare no conflict of interest.

\section{References}

1. Müller, C.; Elliott, J.; Levermann, A. Fertilizing hidden hunger. Nat. Publ. Gr. 2014, 4, 540-541. [CrossRef]

2. Smith, M.R.; Golden, C.D.; Myers, S.S. Potential rise in iron deficiency due to future anthropogenic carbon dioxide emissions. GeoHealth 2017, 1, 248-257. [CrossRef]

3. Umbreit, J. Iron deficiency: A concise review. Am. J. Hematol. 2005, 231, 225-231. [CrossRef] [PubMed]

4. Beal, T.; Massiot, E.; Arsenault, J.E.; Smith, M.R. Global trends in dietary micronutrient supplies and estimated prevalence of inadequate intakes. PLoS ONE 2017, 12, e0175554. [CrossRef] [PubMed]

5. Murgia, I.; Arosio, P.; Tarantino, D.; Soave, C. Biofortification for combating ' hidden hunger ' for iron. Trends Plant Sci. 2012, 17, 47-55. [CrossRef] [PubMed]

6. Rehman, H.M.; Cooper, J.W. Legume biofortification is an underexploited strategy for combatting hidden hunger. Plant Cell Environ. 2018, 42, 52-70. [CrossRef] [PubMed]

7. Rawat, N.; Neelam, K.; Tiwari, V.K.; Dhaliwal, H.S. Review Biofortification of cereals to overcome hidden hunger. Plant Breed. 2013, 132, 437-445.

8. Food, S.; Nestel, P.; Bouis, H.E.; Meenakshi, J.V.; Pfeiffer, W. Biofortification of staple food crops. J. Nutr. 2006, 136, 1064-1067.

9. Bouis, H.E.; Welch, R.M. Biofortification-a sustainable agricultural strategy for reducing micronutrient malnutrition in the global south. Crop Sci. 2010, 50, S-20-S-32. [CrossRef]

10. Garg, M.; Sharma, N.; Sharma, S.; Kapoor, P.; Kumar, A.; Garg, M. Biofortified crops generated by breeding, agronomy, and transgenic approaches are improving lives of millions of people around the world. Front. Nutr. 2018, 5, 12. [CrossRef]

11. Carvalho, S.M.P.; Vasconcelos, M.W. Producing more with less: strategies and novel technologies for plant-based food biofortification. Food Res. Int. 2013, 54, 961-971. [CrossRef]

12. Anderson, J.C.; Appleton, E.; Densmore, D.; Endy, D.; Galdzicki, M.; Gennari, J.H.; Grünberg, R.; Huynh, L.; David, J.; Kahl, L.J.; et al. Status and market potential of transgenic biofortified crops. Nat. Biotechnol. 2015, 33, 25-29.

13. FAO Human vitamin and mineral requirements. In Proceedings of the FAO/WHO expert consultation on human vitamin and mineral requirements, Bangkok, Thailand, 21-30 September 1998. 
14. García-seco, D.; Bonilla, A.; Algar, E.; García-villaraco, A.; Mañero, J.G.; Ramos-solano, B. Enhanced blackberry production using Pseudomonas fluorescens as elicitor. Agron. Sustain. Dev. 2013, 33, 385-392. [CrossRef]

15. Garcia-seco, D.; Zhang, Y.; Gutierrez-ma, F.J.; Martin, C.; Ramos-solano, B. Application of Pseudomonas fluorescens to blackberry under field conditions improves fruit quality by modifying flavonoid metabolism. PLoS ONE 2015, 10, e0142639. [CrossRef]

16. Jinal, H.N.; Gopi, K.; Prittesh, P.; Kartik, V.P.; Amaresan, N. Phytoextraction of iron from contaminated soils by inoculation of iron-tolerant plant growth-promoting bacteria in Brassica juncea L. Czern. Environ. Sci. Pollut. Res. 2019. [CrossRef]

17. Gopalakrishnan, S.; Vadlamudi, S.; Samineni, S.; Kumar, C.V.S. Plant growth- promotion and biofortification of chickpea and pigeonpea through inoculation of biocontrol potential bacteria, isolated from organic soils. Springerplus 2016, 5, 1882. [CrossRef]

18. Pellegrino, E.; Bedini, S. Enhancing ecosystem services in sustainable agriculture: Biofertilization and biofortification of chickpea (Cicer arietinum L.) by arbuscular mycorrhizal fungi. Soil Biol. Biochem. 2014, 68, 429-439. [CrossRef]

19. Sathya, A.; Vijayabharathi, R.; Srinivas, V.; Gopalakrishnan, S. Plant growth-promoting actinobacteria on chickpea seed mineral density: An upcoming complementary tool for sustainable biofortification strategy. 3 Biotech 2016, 6, 138. [CrossRef]

20. Baslam, M.; Garmendia, I.; Goicoechea, N.; Unidad, V.; Icvv, Z. Arbuscular mycorrhizal fungi (AMF) improved growth and nutritional quality of greenhouse-grown lettuce. J. Agric. Food Chem. 2011, 59, 5504-5515. [CrossRef]

21. Kamarudin, A.N.; Seman, I.A.; Palm, M.; Board, O.; Norhana, Z.; Yusof, B. Thiamine biosynthesis gene expression analysis in Elaeis guineensis during interactions with Hendersonia toruloidea. J. Oil Palm Res. 2017, 29, 218-226. [CrossRef]

22. Kamarudin, A.N.; Lai, K.S.; Lamasudin, D.U.; Idris, A.S. Enhancement of thiamine biosynthesis in oil palm seedlings by colonization of endophytic fungus Hendersonia toruloidea. Front. Plant Sci. 2017, 8, 1-8. [CrossRef] [PubMed]

23. Manjunath, M.; Kanchan, A.; Ranjan, K.; Venkatachalam, S.; Prasanna, R.; Ramakrishnan, B.; Hossain, F.; Nain, L.; Shivay, Y.S.; Rai, A.B.; et al. Beneficial cyanobacteria and eubacteria synergistically enhance bioavailability of soil nutrients and yield of okra. Heliyon 2016, 2, e00066. [CrossRef] [PubMed]

24. Rozpądek, P.; Rąpała-Kozik, M.; Wężowicz, K.; Grandin, A.; Karlsson, S.; Ważny, R.; Anielska, T.; Turnau, K. Arbuscular mycorrhiza improves yield and nutritional properties of onion (Allium cepa). Plant Physiol. Biochem. 2016, 107, 264-272. [CrossRef] [PubMed]

25. Wu, Z.; Wu, W.; Zhou, S.; Wu, S. Mycorrhizal inoculation affects $\mathrm{Pb}$ and $\mathrm{Cd}$ accumulation and translocation in pakchoi (Brassica chinensis L.). Pedosphere 2016, 26, 13-26. [CrossRef]

26. Ismail, Y.; McCormick, S.; Hijri, M. The arbuscular mycorrhizal fungus, Glomus irregulare, controls the mycotoxin production of Fusarium sambucinum in the pathogenesis of potato. FEMS Microbiol. Lett. 2013, 348, 46-51. [CrossRef]

27. Shakeel, M.; Rais, A.; Hassan, M.N.; Hafeez, F.Y. Root associated Bacillus sp. improves growth, yield and zinc translocation for basmati rice (Oryza sativa) varieties. Front. Microbiol. 2015, 6, 1286. [CrossRef]

28. Adak, A.; Prasanna, R.; Babu, S.; Bidyarani, N.; Verma, S.; Pal, M.; Shivay, Y.S.; Nain, L. Micronutrient enrichment mediated by plant-microbe interactions and rice cultivation practices. J. Plant Nutr. 2016, 39, 1216-1232. [CrossRef]

29. Wang, Y.; Yang, X.; Zhang, X.; Dong, L.; Zhang, J.; Wei, Y.; Feng, Y.; Lu, L. Improved plant growth and Zn accumulation in grains of rice (Oryza sativa L.) by inoculation of endophytic microbes isolated from a $\mathrm{Zn}$ hyperaccumulator, Sedum alf redii H. J. Agric. Food Chem. 2014, 62, 1783-1791. [CrossRef]

30. Rana, A.; Kabi, S.R.; Verma, S.; Adak, A.; Pal, M.; Shivay, Y.S.; Prasanna, R.; Nain, L. Prospecting plant growth promoting bacteria and cyanobacteria as options for enrichment of macro- and micronutrients in grains in rice-wheat cropping sequence. Cogent Food Agric. 2015, 1. [CrossRef]

31. Dave, S.; Tarafdar, J.C. Stimulatory synthesis of saponin by mycorrhizal fungi in safed musli (Chlorophytum borivilianum) tubers. Int. Res. J. Agric. Sci. Soil Sci. 2011, 1, 137-141. 
32. Gosal, S.K.; Karlupia, A.; Gosal, S.S.; Chhibba, I.M.; Varma, A. Biotization with Piriformospora indica and Pseudomonas fluorescens improves survival rate, nutrient acquisition, field performance and saponin content of micropropagated Chlorophytum sp. Indian J. Biotechnol. 2010, 9, 289-297.

33. Salinas-Ramírez, N.; Escalante-Estrada, J.A.; Rodríguez-González, M.T.; Sosa-Montes, E. Yield and nutritional quality of snap bean in terms of biofertilization. Trop. Subtrop. Agroecosyst. 2011, 13, 347-355.

34. Khalid, M.; Hassani, D.; Bilal, M.; Asad, F.; Huang, D. Influence of bio-fertilizer containing beneficial fungi and rhizospheric bacteria on health promoting compounds and antioxidant activity of Spinacia oleracea L. Bot. Stud. 2017, 58, 35. [CrossRef] [PubMed]

35. Bona, E.; Lingua, G.; Manassero, P.; Cantamessa, S.; Marsano, F.; Todeschini, V.; Copetta, A.; Agostino, G.D.; Massa, N.; Avidano, L.; et al. AM fungi and PGP pseudomonads increase flowering, fruit production, and vitamin content in strawberry grown at low nitrogen and phosphorus levels. Mycorrhiza 2015, 25, 181-193. [CrossRef]

36. Flores-félix, J.D.; Silva, L.R.; Rivera, L.P.; Marcos-garcía, M. Plants probiotics as a tool to produce highly functional fruits: The Case of Phyllobacterium and vitamin C in strawberries. PLoS ONE 2015, 10, e0122281. [CrossRef]

37. Erturk, Y.; Ercisli, S.; Cakmakci, R. Yield and growth response of strawberry to plant growth-promoting Rhizobacteria inoculation. J. Plant Nutr. 2012, 35, 817-826. [CrossRef]

38. Bona, E.; Cantamessa, S.; Massa, N.; Manassero, P.; Marsano, F.; Copetta, A.; Lingua, G.; Agostino, G.D.; Gamalero, E.; Berta, G. Arbuscular mycorrhizal fungi and plant growth-promoting pseudomonads improve yield, quality and nutritional value of tomato: A field study. Mycorrhiza 2017, 27, 1-11. [CrossRef]

39. Hart, M.; Ehret, D.L.; Krumbein, A.; Leung, C.; Murch, S.; Turi, C.; Franken, P. Inoculation with arbuscular mycorrhizal fungi improves the nutritional value of tomatoes. Mycorrhiza 2015, 25, 359-376. [CrossRef]

40. Ochoa-velasco, C.E.; Valadez-blanco, R.; Salas-coronado, R.; Sustaita-rivera, F.; Hernández-carlos, B.; García-ortega, S.; Santos-sánchez, N.F. Effect of nitrogen fertilization and Bacillus licheniformis biofertilizer addition on the antioxidants compounds and antioxidant activity of greenhouse cultivated tomato fruits (Solanum lycopersicum L. var. Sheva). Sci. Hortic. (Amsterdam) 2016, 201, 338-345. [CrossRef]

41. Mäder, P.; Kaiser, F.; Adholeya, A.; Singh, R.; Uppal, H.S.; Sharma, A.K.; Srivastava, R.; Sahai, V.; Aragno, M.; Wiemken, A.; et al. Inoculation of root microorganisms for sustainable wheat-rice and wheat-black gram rotations in India. Soil Biol. Biochem. 2011, 43, 609-619. [CrossRef]

42. Rana, A.; Joshi, M.; Prasanna, R.; Shivay, Y.S.; Nain, L. Biofortification of wheat through inoculation of plant growth promoting rhizobacteria and cyanobacteria. Eur. J. Soil Biol. 2012, 50, 118-126. [CrossRef]

43. Yasin, M.; El-Mehdawi, A.F.; Pilon-Smits, E.A.; Faisal, M. Selenium-fortified wheat: Potential of microbes for biofortification of selenium and other essential nutrients. Int. J. Phytoremed. 2015, 17, 777-786. [CrossRef] [PubMed]

44. Ingraffia, R.; Amato, G.; Frenda, A.S.; Giambalvo, D. Impacts of arbuscular mycorrhizal fungi on nutrient uptake, $\mathrm{N}_{2}$ fixation, $\mathrm{N}$ transfer, and growth in a wheat/faba bean intercropping system. PLoS ONE 2019, 14, e0213672. [CrossRef] [PubMed]

45. Durán, P.; Acuña, J.J.; Jorquera, M.A.; Azcón, R.; Borie, F.; Cornejo, P.; Mora, M.L. Enhanced selenium content in wheat grain by co-inoculation of selenobacteria and arbuscular mycorrhizal fungi: A preliminary study as a potential Se biofortification strategy. J. Cereal Sci. 2013, 57, 275-280. [CrossRef]

46. Kobayashi, T.; Nishizawa, N.K. Iron Uptake, Translocation, and Regulation in Higher Plants. Annu. Rev. Plant Biol. 2012, 63, 131-152. [CrossRef]

47. Jin, C.W.; Ye, Y.Q.; Zheng, S.J. An underground tale: Contribution of microbial activity to plant iron acquisition via ecological processes. Ann. Bot. 2014, 113, 7-18. [CrossRef]

48. Jin, C.W.; Li, G.X.; Yu, X.H.; Zheng, S.J. Plant Fe status affects the composition of siderophore-secreting microbes in the rhizosphere. Ann. Bot. 2010, 105, 835-841. [CrossRef]

49. Ivanov, R.; Brumbarova, T.; Bauer, P. Fitting into the harsh reality: Regulation of iron-deficiency responses in dicotyledonous plants. Mol. Plant 2012, 5, 27-42. [CrossRef]

50. Nozoye, T.; Nagasaka, S.; Kobayashi, T.; Takahashi, M.; Sato, Y.; Sato, Y.; Uozumi, N.; Nakanishi, H.; Nishizawa, N.K. Phytosiderophore efflux transporters are crucial for iron acquisition in graminaceous plants. J. Biol. Chem. 2011, 286, 5446-5454. [CrossRef]

51. Jin, C.W.; He, Y.F.; Tang, C.X.; Wu, P.; Zheng, S.J. Mechanisms of microbially enhanced Fe acquisition in red clover (Trifolium pratense L.). Plant Cell Environ. 2006, 29, 888-897. [CrossRef] 
52. De Santiago, A.; García-López, A.M.; Quintero, J.M.; Avilés, M.; Delgado, A. Effect of Trichoderma asperellum strain T34 and glucose addition on iron nutrition in cucumber grown on calcareous soils. Soil Biol. Biochem. 2013, 57, 598-605. [CrossRef]

53. Philpott, C.C. Iron uptake in fungi: A system for every source. Biochim. Biophys. Acta Mol. Cell Res. 2006, 1763, 636-645. [CrossRef] [PubMed]

54. Schalk, I.J.; Hannauer, M.; Braud, A. New roles for bacterial siderophores in metal transport and tolerance. Environ. Microbiol. 2011, 13, 2844-2854. [CrossRef] [PubMed]

55. Bonnefoy, V.; Holmes, D.S. Genomic insights into microbial iron oxidation and iron uptake strategies in extremely acidic environments. Environ. Microbiol. 2012, 14, 1597-1611. [CrossRef] [PubMed]

56. Curie, C.; Panaviene, Z.; Loulergue, C.; Dellaporta, S.L.; Briat, J.F.; Walker, E.L. Maize yellow stripe1 encodes a membrane protein directly involved in Fe(III) uptake. Nature 2001, 409, 346-349. [CrossRef]

57. Guerinot, M.L.; Yi, Y. Iron: Nutritious, noxious, and not readily available. Plant Physiol. 1994, 104, 815-820. [CrossRef]

58. Jetten, M.S.; Logemann, S.; Muyzer, G.; Robertson, L.A.; De Vries, S.; van Loosdrecht, M.C.; Kuenen, J.G. Novel principles in the microbial conversion of nitrogen compounds. Antonie Van Leeuwenhoek 1997, 71, 75-93. [CrossRef]

59. Illmer, P.; Schinner, F. Solubilization of inorganic calcium phosphates-Solubilization mechanisms. Soil Biol. Biochem. 1995, 27, 257-263. [CrossRef]

60. Zhang, H.; Sun, Y.; Xie, X.; Kim, M.S.; Dowd, S.E.; Pare, P.W. A soil bacterium regulates plant acquisition of iron via deficiency-inducible mechanisms. Plant J. 2009, 58, 568-577. [CrossRef]

61. Jin, C.W.; You, G.Y.; Zheng, S.J. The iron deficiency-induced phenolics secretion plays multiple important roles in plant iron acquisition underground. Plant Signal Behav. 2008, 3, 60-61. [CrossRef]

62. Chen, W.W.; Yang, J.L.; Qin, C.; Jin, C.W.; Mo, J.H.; Ye, T.; Zheng, S.J. Nitric oxide acts downstream of auxin to trigger root ferric-chelate reductase activity in response to iron deficiency in Arabidopsis. Plant Physiol. 2010, 154, 810-819. [CrossRef] [PubMed]

63. Graziano, M.; Lamattina, L. Nitric oxide accumulation is required for molecular and physiological responses to iron deficiency in tomato roots. Plant J. 2007, 52, 949-960. [CrossRef] [PubMed]

64. Garcia, M.J.; Suarez, V.; Romera, F.J.; Alcantara, E.; Perez-Vicente, R. A new model involving ethylene, nitric oxide and Fe to explain the regulation of Fe-acquisition genes in Strategy I plants. Plant Physiol. Biochem. 2011, 49, 537-544. [CrossRef] [PubMed]

65. Seguela, M.; Briat, J.F.; Vert, G.; Curie, C. Cytokinins negatively regulate the root iron uptake machinery in Arabidopsis through a growth-dependent pathway. Plant J. 2008, 55, 289-300. [CrossRef] [PubMed]

66. Wang, B.; Li, Y.; Zhang, W.H. Brassinosteroids are involved in response of cucumber (Cucumis sativus) to iron deficiency. Ann. Bot. 2012, 110, 681-688. [CrossRef]

67. Hayat, R.; Ali, S.; Amara, U.; Khalid, R.; Ahmed, I. Soil beneficial bacteria and their role in plant growth promotion: A review. Ann. Microbiol. 2010, 60, 579-598. [CrossRef]

68. Kim, D.G.; Vargas, R.; Bond-Lamberty, B.; Turetsky, M.R. Effects of soil rewetting and thawing on soil gas fluxes: A review of current literature and suggestions for future research. Biogeosciences 2012, 9, 2459-2483. [CrossRef]

69. Jin, C.W.; Du, S.T.; Shamsi, I.H.; Luo, B.F.; Lin, X.Y. NO synthase-generated NO acts downstream of auxin in regulating Fe-deficiency-induced root branching that enhances Fe-deficiency tolerance in tomato plants. J. Exp. Bot. 2011, 62, 3875-3884. [CrossRef]

70. Meiser, J.; Lingam, S.; Bauer, P. Posttranslational regulation of the iron deficiency basic helix-loop-helix transcription factor FIT is affected by iron and nitric oxide. Plant Physiol. 2011, 157, 2154-2166. [CrossRef]

71. Jäckel, U.; Schnell, S.; Conrad, R. Microbial ethylene production and inhibition of methanotrophic activity in a deciduous forest soil. Soil Biol. Biochem. 2004, 36, 835-840. [CrossRef]

72. Wu, J.; Wang, C.; Zheng, L.; Wang, L.; Chen, Y.; Whelan, J.; Shou, H. Ethylene is involved in the regulation of iron homeostasis by regulating the expression of iron-acquisition-related genes in Oryza sativa. J. Exp. Bot. 2011, 62, 667-674. [CrossRef] [PubMed]

73. Terpolilli, J.J.; Hood, G.A.; Poole, P.S. What determines the efficiency of $\mathrm{N}_{2}$-fixing Rhizobium-legume symbioses? Adv. Microb. Physiol. 2012, 60, 325-389. [PubMed] 
74. Slatni, T.; Dell'Orto, M.; Ben Salah, I.; Vigani, G.; Smaoui, A.; Gouia, H.; Zocchi, G.; Abdelly, C. Immunolocalization of $\mathrm{H}^{+}$-ATPase and IRT1 enzymes in $\mathrm{N}_{2}$-fixing common bean nodules subjected to iron deficiency. J. Plant Physiol. 2012, 169, 242-248. [CrossRef] [PubMed]

75. Mishra, P.K.; Bisht, S.C.; Ruwari, P.; Joshi, G.K.; Singh, G.; Bisht, J.K.; Bhatt, J.C. Bioassociative effect of cold tolerant Pseudomonas spp. and Rhizobium leguminosarum-PR1 on iron acquisition, nutrient uptake and growth of lentil (Lens culinaris L.). Eur. J. Soil Biol. 2011, 47, 35-43. [CrossRef]

76. Mishra, P.K.; Bisht, S.C.; Mishra, S.; Selvakumar, G.; Bisht, J.K.; Gupta, H.S. Coinoculation of Rhizobium Leguminosarum-PR1 with a cold tolerant Pseudomonas sp. improves iron acquisition, nutrient uptake and growth of field pea (Pisum Sativum L.). J. Plant Nutr. 2012, 35, 243-256. [CrossRef]

77. Welch, R.M. Breeding strategies for biofortified staple plant foods to reduce micronutrient malnutrition globally. J. Nutr. 2002, 132, 495s-499s. [CrossRef]

78. Maret, W.; Sandstead, H.H. Zinc requirements and the risks and benefits of zinc supplementation. J. Trace Elem. Med. Biol. 2006, 20, 3-18. [CrossRef]

79. Alloway, B.J. Micronutrients and crop production: An introduction. In Micronutrient Deficiencies in Global Crop Production; Alloway, B.J., Ed.; Springer: Dordrecht, the Netherlands, 2008; pp. 1-39. ISBN 978-1-4020-6860-7.

80. Tavallali, V.; Rahemi, M.; Maftoun, M.; Panahi, B.; Karimi, S.; Ramezanian, A.; Vaezpour, M. Scientia horticulturae zinc influence and salt stress on photosynthesis, water relations, and carbonic anhydrase activity in pistachio. Sci. Hortic. 2009, 123, 272-279. [CrossRef]

81. Cakamk, I.; Marschener, H. Enhanced Superoxide Radical Production in Roots of Zinc-Deficient Plants. J. Exp. Bot. 1988, 39, 1449-1460. [CrossRef]

82. Lindsay, W.L.; Norvell, W.A. Development of a DTPA soil test for zinc, iron, manganese, and copper. Soil Sci. Soc. Am. J. 1978, 42, 421-428. [CrossRef]

83. Hussain, A.; Zahir, Z.A.; Asghar, H.N.; Ahmad, M.; Jamil, M.; Naveed, M.; Zaman Akhtar, M.F.U. Zinc solubilizing bacteria for zinc biofortification in cereals: a step toward sustainable nutritional security. In Role of Rhizospheric Microbes in Soil: Volume 2: Nutrient Management and Crop Improvement; Meena, V.S., Ed.; Springer: Singapore, 2018; pp. 203-227. ISBN 978-981-13-0044-8.

84. Imran, M.; Arshad, M.; Khalid, A.; Kanwal, S.; Crowley, D.E. Perspectives of rhizosphere microflora for improving Zn bioavailability and acquisition by higher plants. Int. J. Agric. Biol. 2014, 16, 653-662.

85. Saravanan, V.S.; Madhaiyan, M.; Thangaraju, M. Solubilization of zinc compounds by the diazotrophic, plant growth promoting bacterium Gluconacetobacter diazotrophicus. Chemosphere 2007, 66, 1794-1798. [CrossRef] [PubMed]

86. Paul, E.A. Soil microbiology and biochemistry in perspective. In Soil Microbiology and Biochemistry; Paul, E.A., Clark, F.E., Eds.; Academic Press: San Diego, CA, USA, 1989; pp. 1-10. ISBN 978-0-12-546805-3.

87. Ahmad, M.; Nadeem, S.M.; Naveed, M.; Zahir, Z.A. Potassium-solubilizing bacteria and their application in agriculture. In Potassium Solubilizing Microorganisms for Sustainable Agriculture; Meena, V.S., Maurya, B.R., Verma, J.P., Meena, R.S., Eds.; Springer: New Delhi, India, 2016; pp. 293-313. ISBN 978-81-322-2776-2.

88. Biari, A.; Gholami, A.; Rahmani, H.A. Growth promotion and enhanced nutrient uptake of maize (Zea mays L.) by application of plant growth promoting Rhizobacteria in arid region of Iran. J. Biol. Sci. 2008, 8, 1015-1020.

89. Goteti, P.K.; Emmanuel, L.D.A.; Desai, S.; Shaik, M.H.A. Prospective zinc solubilising bacteria for enhanced nutrient uptake and growth promotion in maize (Zea mays L.). Int. J. Microbiol. 2013, 1, 869697. [CrossRef]

90. Hafeez, F.Y.; Hameed, S.; Zaidi, A.H.; Malik, K.A. Techniques for sustainable agriculture. In Biofertilizers for Sustainable Agriculture; Azam, F., Iqbal, M.M., Inayatullah, C., Malik, K.A., Eds.; NIAB: Faisalabad, Pakistan, 2002; pp. 67-73.

91. Tariq, M.; Hameed, S.; Malik, K.A.; Hafeez, F.Y. Plant root associated bacteria for zinc mobilization in rice. Pakistan J. Bot. 2007, 39, 245.

92. Ramesh, A.; Sharma, S.K.; Sharma, M.P.; Yadav, N.; Joshi, O.P. Inoculation of zinc solubilizing Bacillus aryabhattai strains for improved growth, mobilization and biofortification of zinc in soybean and wheat cultivated in Vertisols of central India. Appl. Soil Ecol. 2014, 73, 87-96. [CrossRef]

93. Ullah, M.A.; Yusuf, F. Biofertilizer/biopesticide potentiality of zinc solubilizing Pseudomonas aeruginosa FA-9 and Enterobactersp. FA-11 isolated from the wheat rhizosphere grown in arid zone. Access Microbiol. 2019, 1. [CrossRef]

94. Sultana, U.; Desai, S.; Reddy, G.; Prasad, T. Zinc solubilizing plant growth promoting microbes produce zinc nanoparticles. bioRxiv 2019, 602219. [CrossRef] 
95. Costerousse, B.; Schönholzer-Mauclaire, L.; Frossard, E.; Thonar, C. Identification of heterotrophic zinc mobilization processes among bacterial strains isolated from wheat rhizosphere (Triticum aestivum L.). Appl. Environ. Microbiol. 2017, 84, e01715-17. [CrossRef]

96. Rose, M.T.; Pariasca-Tanaka, J.; Rose, T.J.; Wissuwa, M. Bicarbonate tolerance of Zn-efficient rice genotypes is not related to organic acid exudation, but to reduced solute leakage from roots. Funct. Plant Biol. 2011, 38, 493-504. [CrossRef]

97. Impa, S.M.; Johnson-Beebout, S.E. Mitigating zinc deficiency and achieving high grain $\mathrm{Zn}$ in rice through integration of soil chemistry and plant physiology research. Plant Soil 2012, 361, 3-41. [CrossRef]

98. Havlin, J.L.; Beaton, J.D.; Tisdale, S.L.; Nelson, W.L. Soil Fertility and Fertilizers: An Introduction to Nutrient Management, 7th ed.; Pearson Education: Upper Saddle River, NJ, USA, 2005.

99. Wu, S.C.; Cheung, K.C.; Luo, Y.M.; Wong, M.H. Effects of inoculation of plant growth-promoting rhizobacteria on metal uptake by Brassica juncea. Environ. Pollut. 2006, 140, 124-135. [CrossRef] [PubMed]

100. Fasim, F.; Ahmed, N.; Parsons, R.; Gadd, G.M. Solubilization of zinc salts by a bacterium isolated from the air environment of a tannery. FEMS Microbiol. Lett. 2002, 213, 1-6. [CrossRef]

101. Saravanan, V.S.; Subramoniam, S.R.; Raj, S.A. Assessing in vitro solubilization potential of different zinc solubilizing bacterial (zsb) isolates. Brazilian J. Microbiol. 2004, 35, 121-125. [CrossRef]

102. Martino, E.; Perotto, S.; Parsons, R.; Gadd, G.M. Solubilization of insoluble inorganic zinc compounds by ericoid mycorrhizal fungi derived from heavy metal polluted sites. Soil Biol. Biochem. 2003, 35, 133-141. [CrossRef]

103. Subramanian, K.S.; Jayalakshmi, K.; Ramachandran, V.T. Role of arbuscular mycorrhizal fungus (Glomus intraradices) (fungus aided) in zinc nutrition of maize. J. Agric. Biotechnol. Sustain. Dev. 2009, 1, 29-38.

104. Obrador, A.; Novillo, J.; Alvarez, J.M. Mobility and availability to plants of two zinc sources applied to a calcareous Soil. Soil Sci. Soc. Am. J. 2003, 67, 564-572. [CrossRef]

105. Whiting, S.N.; de Souza, M.P.; Terry, N. Rhizosphere bacteria mobilize Zn for hyperaccumulation by Thlaspicaerulescens. Environ. Sci. Technol. 2001, 35, 3144-3150. [CrossRef]

106. The World Food Prize- Improving The Quality, Quantity and Availability of Food in the World. Available online: https://www.worldfoodprize.org/en/laureates/2010_2017_laureates/2016_andrade_mwanga_low_ and_bouis/ (accessed on 29 September 2019).

107. Giuliano, G. Provitamin A biofortification of crop plants: A gold rush with many miners. Curr. Opin. Biotechnol. 2017, 44, 169-180. [CrossRef]

108. Ye, X.; Al-babili, S.; Klöti, A.; Zhang, J.; Lucca, P.; Beyer, P.; Potrykus, I. Engineering the provitamin A ( $\beta$-carotene) biosynthetic pathway into (carotenoid-free) rice endosperm. Science 2000, 287, 303-306. [CrossRef]

109. Golden Rice- International Rice Research Institute. Available online: https://www.irri.org/golden-rice (accessed on 29 September 2019).

110. Roje, S. Vitamin B biosynthesis in plants. Phytochemistry 2007, 68, 1904-1921. [CrossRef] [PubMed]

111. Smirnoff, N.; Conklin, P.L.; Loewus, F.A. Biosynthesis of ascorbic acid in plants: A renaissance. Annu. Rev. Plant Physiol. Plant Mol. Biol. 2001, 52, 437-467. [CrossRef] [PubMed]

112. Mozafar, A. Enrichment of some B-vitamins in plants with application of organic fertilizers. Plant Soil 1994, 167, 305-311. [CrossRef]

113. Goyer, A. Thiamin biofortification of crops. Curr. Opin. Biotechnol. 2017, 44, 1-7. [CrossRef] [PubMed]

114. Pourcel, L.; Moulin, M.; Fitzpatrick, T.B. Examining strategies to facilitate vitamin B 1 biofortification of plants by genetic engineering. Front. Plant Sci. 2013, 4, 1-8. [CrossRef] [PubMed]

115. Dong, W.; Thomas, N.; Ronald, P.C.; Goyer, A. Overexpression of thiamin biosynthesis genes in rice increases leaf and unpolished grain thiamin content but not resistance to Xanthomonas oryzae pv. oryzae. Front. Plant Sci. 2016, 7, 616. [CrossRef] [PubMed]

116. Antoniani, C.; Monzini, A. The vitamin content of produce and products on the farm. III. Vitamin B i content of fodder from meadows irrigated by sewage as compared with that irrigated by clean water. Ann. Sper. Agrar. 1950, 4, 625-630.

117. Wilberg, E. Über die Qualitfit von Spinat aus “biologischem Anban”. Landwirtsch. Forsch 1972, 25, 167-169.

118. Singh, R.D.; Dhar, N.R. Effect of organic matter without and with rockphosphate on crop yield, quality and soil characteristics. Indian J. Agric. Sci. 1986, 56, 539-543. 
119. Mozafar, A.; Oertli, J.J. Uptake of a microbially-produced vitamin ( $\left.\mathrm{B}_{12}\right)$ by soybean roots. Plant Soil 1992, 1, 23-30. [CrossRef]

120. Gray, L.F.; Daniel, L.J. Studies of vitamin $B_{12}$ in turnip greens. J. Nutr. 1959, 10, 623-634. [CrossRef] [PubMed]

121. Robbins, W.J.; Hervey, A.; Stebbins, M.E. Studies on euglena and Vitamin $B_{12}$. Bull. Torrey Bot. 1950, 77, 423-441. [CrossRef]

122. Chadare, F.J.; Idohou, R.; Nago, E.; Affonfere, M.; Hounhouigan, D.J.; Agossadou, J.; Kévin, T.; Christel, F.; Sewanou, K.; Azokpota, P.; et al. Conventional and food-to-food fortification: An appraisal of past practices and lessons learned. Food Sci. Nutr. 2019, 7, 2781-2795. [CrossRef] [PubMed]

123. Locato, V.; Cimini, S.; De Gara, L. Strategies to increase vitamin C in plants: From plant defense perspective to food biofortification. Front. Plant Sci. 2013, 4, 1-12. [CrossRef] [PubMed]

124. Olowokere, F.A. Effect of inorganic and organo-mineral fertilizers on soil properties and nutrient composition of pepper (Capsicum spp.). J. Agric. Sci. Environ. 2014, 14, 82-96.

125. Zhang, C.; Liu, J.; Zhang, Y. Overexpression of SlGMEs leads to ascorbate accumulation with enhanced oxidative stress, cold, and salt tolerance in tomato. Plant Cell Rep. 2011, 30, 389-398. [CrossRef]

126. Jiménez-Gómez, A.; Celador-Lera, L.; Fradejas-Bayón, M.; Rivas, R. Plant probiotic bacteria enhance the quality of fruit and horticultural crops. AIMS Microbiol. 2017, 3, 483-501.

127. Baslam, M.; Garmendia, I.; Goicoechea, N. Enhanced accumulation of vitamins, nutraceuticals and minerals in lettuces associated with arbuscular mycorrhizal fungi (AMF): A question of interest for both vegetables and humans. Agriculture 2013, 3, 188-209. [CrossRef]

128. Kaushik, B.D.; Venkatarman, G.S. Effect of algal inoculation on the yield and vitamin C content of two varieties of tomato. Plant Soil 1979, 52, 135-137. [CrossRef]

129. Prlak, L.; Köse, M. Effects of plant growth promoting Rhizobacteria on yield and some fruit properties of strawberry. J. Plant Nutr. 2009, 32. [CrossRef]

130. Birt, D.F. Flavonoids. Adv. Nutr. 2013, 4, 576-577. [CrossRef] [PubMed]

131. Ruiz-Cruz, S.; Chaparro-Hernández, S.; Hernández-Ruiz, K.L.; Cira-Chávez, L.A.; Estrada-Alvarado, M.I.; Gassos Ortega, L.E.; Ornelas-Paz, J.d.J.; Lopez Mata, M.A. Flavonoids: Important biocompounds in food. In Flavonoids-from Bosynthesis To Human Health; IntechOpen: London, UK, 2017; pp. 353-369.

132. Scarano, A.; Chieppa, M.; Santino, A. Looking at flavonoid biodiversity in horticultural crops: A colored mine with nutritional benefits. Plants 2018, 7, 98. [CrossRef] [PubMed]

133. Bovy, A.; De Vos, R.; Kemper, M.; Schijlen, E.; Pertejo, A.; Muir, S.; Collins, G.; Robinson, S.; Verhoeyen, M.; Hughes, S.; et al. High-flavonol tomatoes resulting from the heterologous expression of the maize transcription factor genes LC and C1. Plant Cell 2002, 14, 2509-2526. [CrossRef] [PubMed]

134. Palermo, M.; Pellegrini, N.; Fogliano, V. The effect of cooking on the phytochemical content of vegetables. J. Sci. Food Agric. 2014, 94, 1057-1070. [CrossRef] [PubMed]

135. Güçlü-Üstündağ, Ö.; Mazza, G. Saponins: Properties, applications and processing. Crit. Rev. Food Sci. Nutr. 2007, 47, 231-258. [CrossRef]

136. Kim, S.; Park, S.; Kang, S.; Kang, H.; Oh, H.; Bae, C. Hypocholesterolemic property of Yucca schidigera and Quillaja saponaria extracts in human body. Arch. Pharm. Res. 2003, 26, 1042-1046. [CrossRef]

137. Huang, Z.; Lin, J.; Cheng, Z.; Xu, M.; Guo, M.; Huang, X.; Yang, Z. Production of oleanane-type sapogenin in transgenic rice via expression of $\beta$-amyrin synthase gene from Panax japonicus C. A. Mey. BMC Biotechnol. 2015, 15, 45. [CrossRef]

138. Wu, H.; Yang, H.; You, X.; Li, Y. Diversity of endophytic fungi from roots of Panax ginseng and their saponin yield capacities. Springerplus 2013, 2, 107. [CrossRef]

139. Microbial Root Endophytes; Schulz, B.; Boyle, C.; Sieber, T. (Eds.) Springer: New York, NY, USA, 2006; ISBN 9783540335252.

140. Bacon, C.W.; White, J.F., Jr. Functions, mechanisms and regulation of endophytic and epiphytic microbial communities of plants. Symbiosis 2016, 68, 87-98. [CrossRef]

141. Jiang, Y.; Wang, W.; Xie, Q.; Liu, N.; Liu, L.; Wang, D.; Zhang, X.; Yang, C.; Chen, X.; Tang, D.; et al. Plants transfer lipids to sustain colonization by mutualistic mycorrhizal and parasitic fungi. Science 2017, 356, 1172-1175. [CrossRef]

142. Luginbuehl, L.H.; Menard, G.N.; Kurup, S.; Van Erp, H.; Radhakrishnan, G.V.; Breakspear, A.; Oldroyd, G.E.D.; Eastmond, P.J. Fatty acids in arbuscular mycorrhizal fungi are synthesized by the host plant. Science 2017, 356, 1175-1178. [CrossRef] [PubMed] 
143. Zhang, Q.; Blaylock, L.A.; Harrison, M.J. Two Medicago truncatula half-ABC transporters are essential for arbuscule development in arbuscular mycorrhizal symbiosis. Plant Cell 2010, 22, 1483-1497. [CrossRef] [PubMed]

144. Fourcroy, P.; Siso-Terraza, P.; Sudre, D.; Saviron, M.; Reyt, G.; Gaymard, F.; Abadia, A.; Abadia, J.; Alvarez-Fernandez, A.; Briat, J.F. Involvement of the ABCG37 transporter in secretion of scopoletin and derivatives by Arabidopsis roots in response to iron deficiency. New Phytol. 2014, 201, 155-167. [CrossRef] [PubMed]

145. Commoner, B. Cost-risk-benefit analysis of nitrogen fertilization: A case history. Ambio 1977, 6, 157-161.

146. Carlsson, G.; Huss-Danell, K. Nitrogen fixation in perennial forage legumes in the field. Plant Soil 2003, 253, 353-372. [CrossRef]

147. Peoples, M.B.; Herridge, D.F.; Alves, B.R.; Urquiaga, S.; Boddey, R.M.; Dakora, F.D.; Bhattarai, S.; Maskey, S.L.; Sampet, C.; Rerkasem, B.; et al. The contributions of nitrogen-fixing crop legumes to the productivity of agricultural systems. Symbiosis 2009, 48, 1-17. [CrossRef]

148. Hestrin, R.; Hammer, E.C.; Mueller, C.W.; Lehmann, J. Synergies between mycorrhizal fungi and soil microbial communities increase plant nitrogen acquisition. Commun. Biol. 2019, 2, 233. [CrossRef]

149. Behie, S.W.; Zelisko, P.M.; Bidochka, M.J. Endophytic insect-parasitic fungi translocate nitrogen directly from insects to plants. Science 2012, 336, 1576-1578. [CrossRef]

150. Singh, D.; Rajawat, M.V.S.; Kaushik, R.; Prasanna, R.; Saxena, A.K. Beneficial role of endophytes in biofortification of $\mathrm{Zn}$ in wheat genotypes varying in nutrient use efficiency grown in soils sufficient and deficient in Zn. Plant Soil 2017, 416, 107-116. [CrossRef]

151. Bharadwaj, D.P.; Alstrom, S.; Lundquist, P.O. Interactions among Glomus irregulare, arbuscular mycorrhizal spore-associated bacteria, and plant pathogens under in vitro conditions. Mycorrhiza 2012, 22, 437-447. [CrossRef]

152. Saridis, G.; Chorianopoulou, S.N.; Ventouris, Y.E.; Sigalas, P.P.; Bouranis, D.L. An Exploration of the Roles of Ferric Iron Chelation-Strategy Components in the Leaves and Roots of Maize Plants. Plants (Basel, Switzerland) 2019, 8, 133. [CrossRef] [PubMed]

153. Chorianopoulou, S.N.; Saridis, Y.I.; Dimou, M.; Katinakis, P.; Bouranis, D.L. Arbuscular mycorrhizal symbiosis alters the expression patterns of three key iron homeostasis genes, ZmNAS1, ZmNAS3, and ZmYS1, in S deprived maize plants. Front. Plant Sci. 2015, 6, 257. [CrossRef] [PubMed]

154. Hacquard, S.; Garrido-Oter, R.; Gonzalez, A.; Spaepen, S.; Ackermann, G.; Lebeis, S.; McHardy, A.C.; Dangl, J.L.; Knight, R.; Ley, R.; et al. Microbiota and host nutrition across plant and animal kingdoms. Cell Host Microbe 2015, 17, 603-616. [CrossRef] [PubMed]

155. El Zahar Haichar, F.; Santaella, C.; Heulin, T.; Achouak, W. Root exudates mediated interactions belowground. Soil Biol. Biochem. 2014, 77, 69-80. [CrossRef]

156. Samain, E.; van Tuinen, D.; Jeandet, P.; Aussenac, T.; Selim, S. Biological control of septoria leaf blotch and growth promotion in wheat by Paenibacillus sp. strain B2 and Curtobacterium plantarum strain EDS. Biol. Control 2017, 114, 87-96. [CrossRef]

157. Zhalnina, K.; Louie, K.B.; Hao, Z.; Mansoori, N.; da Rocha, U.N.; Shi, S.; Cho, H.; Karaoz, U.; Loqué, D.; Bowen, B.P.; et al. Dynamic root exudate chemistry and microbial substrate preferences drive patterns in rhizosphere microbial community assembly. Nat. Microbiol. 2018, 3, 470-480. [CrossRef]

158. Sasse, J.; Martinoia, E.; Northen, T. Feed your friends: Do plant exudates shape the root microbiome? Trends Plant Sci. 2018, 23, 25-41. [CrossRef]

159. Knee, E.M.; Gong, F.C.; Gao, M.; Teplitski, M.; Jones, A.R.; Foxworthy, A.; Mort, A.J.; Bauer, W.D. Root mucilage from pea and its utilization by rhizosphere bacteria as a sole carbon source. Mol. Plant Microbe Interact. 2001, 14, 775-784. [CrossRef]

160. Hennion, N.; Durand, M.; Vriet, C.; Doidy, J.; Maurousset, L.; Lemoine, R.; Pourtau, N. Sugars en route to the roots. Transport, metabolism and storage within plant roots and towards microorganisms of the rhizosphere. Physiol. Plant 2019, 165, 44-57. [CrossRef]

161. Jaeger, C.H., 3rd; Lindow, S.E.; Miller, W.; Clark, E.; Firestone, M.K. Mapping of sugar and amino acid availability in soil around roots with bacterial sensors of sucrose and tryptophan. Appl. Environ. Microbiol. $1999,65,2685-2690$. 
162. Carvalhais, L.C.; Dennis, P.G.; Fedoseyenko, D.; Hajirezaei, M.-R.; Borriss, R.; von Wirén, N. Root exudation of sugars, amino acids, and organic acids by maize as affected by nitrogen, phosphorus, potassium, and iron deficiency. J. Plant Nutr. Soil Sci. 2011, 174, 3-11. [CrossRef]

163. Flugge, U.I.; Hausler, R.E.; Ludewig, F.; Gierth, M. The role of transporters in supplying energy to plant plastids. J. Exp. Bot. 2011, 62, 2381-2392. [CrossRef] [PubMed]

164. Allard-Massicotte, R.; Tessier, L.; Lecuyer, F.; Lakshmanan, V.; Lucier, J.F.; Garneau, D.; Caudwell, L.; Vlamakis, H.; Bais, H.P.; Beauregard, P.B. Bacillus subtilis early colonization of Arabidopsis thaliana roots involves multiple chemotaxis receptors. MBio 2016, 7, 1616-1664. [CrossRef] [PubMed]

165. Moe, L.A. Amino acids in the rhizosphere: From plants to microbes. Am. J. Bot. 2013, 100, $1692-1705$. [CrossRef]

166. Xu, W.H.; Wang, H.X.; Liu, H.; Xiong, Z.T.; Singh, B. Sigle and combined pollution of zinc and Cadmium influence on root exudates and Zn, Cd forms in rygrass. Acta Sci. Circumstantiae 2007, 28, 2089-2095.

167. Ahmadzadeh, F.; Khoshgoftarmanesh, A.H. Release of phytosiderophores from roots of wheat and triticale under nickel-deficient conditions. J. Plant Nutr. Soil Sci. 2019, 182, 708-714. [CrossRef]

168. Gillissen, B.; Burkle, L.; Andre, B.; Kuhn, C.; Rentsch, D.; Brandl, B.; Frommer, W.B. A new family of high-affinity transporters for adenine, cytosine, and purine derivatives in Arabidopsis. Plant Cell 2000, 12, 291-300. [CrossRef]

169. Desimone, M.; Catoni, E.; Ludewig, U.; Hilpert, M.; Schneider, A.; Kunze, R.; Tegeder, M.; Frommer, W.B.; Schumacher, K. A novel superfamily of transporters for allantoin and other oxo derivatives of nitrogen heterocyclic compounds in Arabidopsis. Plant Cell 2002, 14, 847-856. [CrossRef]

170. Doornbos, R.F.; van Loon, L.C.; Bakker, P.A.H.M. Impact of root exudates and plant defense signaling on bacterial communities in the rhizosphere. A review. Agron. Sustain. Dev. 2012, 32, 227-243. [CrossRef]

171. Carvalhais, L.C.; Dennis, P.G.; Fan, B.; Fedoseyenko, D.; Kierul, K.; Becker, A.; von Wiren, N.; Borriss, R. Linking plant nutritional status to plant-microbe interactions. PLoS ONE 2013, 8, e68555. [CrossRef]

172. Ziegler, J.; Schmidt, S.; Chutia, R.; Muller, J.; Bottcher, C.; Strehmel, N.; Scheel, D.; Abel, S. Non-targeted profiling of semi-polar metabolites in Arabidopsis root exudates uncovers a role for coumarin secretion and lignification during the local response to phosphate limitation. J. Exp. Bot. 2016, 67, 1421-1432. [CrossRef] [PubMed]

173. Qin, R.; Hirano, Y.; Brunner, I. Exudation of organic acid anions from poplar roots after exposure to $\mathrm{Al}$, $\mathrm{Cu}$ and Zn. Tree Physiol. 2007, 27, 313-320. [CrossRef] [PubMed]

174. Stringlis, I.A.; Yu, K.; Feussner, K.; de Jonge, R.; Van Bentum, S.; Van Verk, M.C.; Berendsen, R.L.; Bakker, P.A.H.M.; Feussner, I.; Pieterse, C.M.J. MYB72-dependent coumarin exudation shapes root microbiome assembly to promote plant health. Proc. Natl. Acad. Sci. USA 2018, 115, E5213. [CrossRef] [PubMed]

175. Lundberg, D.S.; Teixeira, P.J.P.L. Root-exuded coumarin shapes the root microbiome. Proc. Natl. Acad. Sci. USA 2018, 115, 5629. [CrossRef]

176. Micallef, S.A.; Shiaris, M.P.; Colon-Carmona, A. Influence of Arabidopsis thaliana accessions on rhizobacterial communities and natural variation in root exudates. J. Exp. Bot. 2009, 60, 1729-1742. [CrossRef] [PubMed]

177. Bulgarelli, D.; Garrido-Oter, R.; Munch, P.C.; Weiman, A.; Droge, J.; Pan, Y.; McHardy, A.C.; Schulze-Lefert, P. Structure and function of the bacterial root microbiota in wild and domesticated barley. Cell Host Microbe 2015, 17, 392-403. [CrossRef]

178. Van Nuland, M.E.; Ware, I.M.; Bailey, J.K.; Schweitzer, J.A. Ecosystem feedbacks contribute to geographic variation in plant-soil eco-evolutionary dynamics across a fertility gradient. Funct. Ecol. 2019, 33, 95-106. [CrossRef]

179. Chaparro, J.M.; Badri, D.V.; Bakker, M.G.; Sugiyama, A.; Manter, D.K.; Vivanco, J.M. Correction: Root exudation of phytochemicals in Arabidopsis follows specific patterns that are developmentally programmed and correlate with soil microbial functions. PLoS ONE 2013, 8, e55731. [CrossRef]

180. Shi, S.; Nuccio, E.E.; Shi, Z.J.; He, Z.; Zhou, J.; Firestone, M.K. The interconnected rhizosphere: High network complexity dominates rhizosphere assemblages. Ecol. Lett. 2016, 19, 926-936. [CrossRef]

181. Lundberg, D.S.; Lebeis, S.L.; Paredes, S.H.; Yourstone, S.; Gehring, J.; Malfatti, S.; Tremblay, J.; Engelbrektson, A.; Kunin, V.; Del Rio, T.G.; et al. Defining the core Arabidopsis thaliana root microbiome. Nature 2012, 488, 86-90. [CrossRef] 
182. Dombrowski, N.; Schlaeppi, K.; Agler, M.T.; Hacquard, S.; Kemen, E.; Garrido-Oter, R.; Wunder, J.; Coupland, G.; Schulze-Lefert, P. Root microbiota dynamics of perennial Arabis alpina are dependent on soil residence time but independent of flowering time. Isme J. 2017, 11, 43-55. [CrossRef] [PubMed]

183. Fitzpatrick, C.R.; Copeland, J.; Wang, P.W.; Guttman, D.S.; Kotanen, P.M. Assembly and ecological function of the root microbiome across angiosperm plant species. Proc. Natl. Acad. Sci. USA 2018, 115, E1157-E1165. [CrossRef] [PubMed]

184. DeAngelis, K.M.; Ji, P.; Firestone, M.K.; Lindow, S.E. Two novel bacterial biosensors for detection of nitrate availability in the rhizosphere. Appl. Environ. Microbiol. 2005, 71, 8537-8547. [CrossRef] [PubMed]

185. De Angelis, K.M.; Brodie, E.L.; DeSantis, T.Z.; Andersen, G.L.; Lindow, S.E.; Firestone, M.K. Selective progressive response of soil microbial community to wild oat roots. Isme J. 2009, 3, 168-178. [CrossRef]

186. Massalha, H.; Korenblum, E.; Malitsky, S.; Shapiro, O.H.; Aharoni, A. Live imaging of root-bacteria interactions in a microfluidics setup. Proc. Natl. Acad. Sci. USA 2017, 114, 4549-4554. [CrossRef]

187. Kawasaki, A.; Donn, S.; Ryan, P.R.; Mathesius, U.; Devilla, R.; Jones, A.; Watt, M. Microbiome and exudates of the root and rhizosphere of Brachypodium distachyon, a model for wheat. PLoS ONE 2016, 11, e0164533. [CrossRef]

188. Watson, B.S.; Bedair, M.F.; Urbanczyk-Wochniak, E.; Huhman, D.V.; Yang, D.S.; Allen, S.N.; Li, W.; Tang, Y.; Sumner, L.W. Integrated metabolomics and transcriptomics reveal enhanced specialized metabolism in Medicago truncatula root border cells. Plant Physiol. 2015, 167, 1699-1716. [CrossRef]

189. Vicre, M.; Santaella, C.; Blanchet, S.; Gateau, A.; Driouich, A. Root border-like cells of Arabidopsis. Microscopical characterization and role in the interaction with rhizobacteria. Plant Physiol. 2005, 138, 998-1008. [CrossRef]

190. Neumann, G.; Martinoia, E. Cluster roots-an underground adaptation for survival in extreme environments. Trends Plant Sci. 2002, 7, 162-167. [CrossRef]

191. Weisskopf, L.; Heller, S.; Eberl, L. Burkholderia species are major inhabitants of white lupin cluster roots. Appl. Environ. Microbiol. 2011, 77, 7715-7720. [CrossRef]

192. Weisskopf, L.; Abou-Mansour, E.; Fromin, N.; Tomasi, N.; Santelia, D.; Edelkott, I.; Neumann, G.; Aragno, M.; Tabacchi, R.; Martinoia, E. White lupin has developed a complex strategy to limit microbial degradation of secreted citrate required for phosphate acquisition. Plant Cell Environ. 2006, 29, 919-927. [CrossRef] [PubMed]

193. Eisenhauer, N.; Dobies, T.; Cesarz, S.; Hobbie, S.E.; Meyer, R.J.; Worm, K.; Reich, P.B. Plant diversity effects on soil food webs are stronger than those of elevated $\mathrm{CO}_{2}$ and $\mathrm{N}$ deposition in a long-term grassland experiment. Proc. Natl. Acad. Sci. USA 2013, 110, 6889-6894. [CrossRef] [PubMed]

194. Prober, S.M.; Leff, J.W.; Bates, S.T.; Borer, E.T.; Firn, J.; Harpole, W.S.; Lind, E.M.; Seabloom, E.W.; Adler, P.B.; Bakker, J.D.; et al. Plant diversity predicts beta but not alpha diversity of soil microbes across grasslands worldwide. Ecol. Lett. 2015, 18, 85-95. [CrossRef] [PubMed]

195. Steinauer, K.; Chatzinotas, A.; Eisenhauer, N. Root exudate cocktails: The link between plant diversity and soil microorganisms? Ecol. Evol. 2016, 6, 7387-7396. [CrossRef] [PubMed]

196. Agler, M.T.; Ruhe, J.; Kroll, S.; Morhenn, C.; Kim, S.T.; Weigel, D.; Kemen, E.M. Microbial hub taxa link host and abiotic factors to plant microbiome variation. PLoS Biol. 2016, 14, e1002352. [CrossRef]

197. White, P.J.; Broadley, M.R. Biofortification of crops with seven mineral elements often lacking in human diets-iron, zinc, copper, calcium, magnesium, selenium and iodine. New Phytol. 2009, 182, 49-84. [CrossRef]

(C) 2019 by the authors. Licensee MDPI, Basel, Switzerland. This article is an open access article distributed under the terms and conditions of the Creative Commons Attribution (CC BY) license (http://creativecommons.org/licenses/by/4.0/). 